\title{
24-Epibrassinolide modulates primary metabolites, antioxidants, and phytochelatins in Acutodesmus obliquus exposed to lead stress
}

\author{
Marta Talarek-Karwel $^{1} \cdot$ Andrzej Bajguz $^{1}$ (1) • Alicja Piotrowska-Niczyporuk ${ }^{1}$
}

Received: 1 August 2019 /Revised and accepted: 14 October 2019/Published online: 16 November 2019

(C) The Author(s) 2019

\begin{abstract}
Aquatic organisms are exposed to many stressors, e.g., heavy metals. Brassinosteroids, a plant hormone group, can effectively stimulate plants to defend against the negative impact of a heavy metal. The present study was conducted with an aim to find out the influence of 24-epibrassinolide (EBL) on Acutodesmus obliquus treated with 0.01 and $500 \mu \mathrm{M}$ of lead $(\mathrm{Pb})$ ions during 7 days of cultivation. $\mathrm{Pb}$ has a toxic effect on algal cultures because it limits both the growth and development and induces oxidative stress. Simultaneously, $1 \mu \mathrm{M}$ EBL was involved in protecting algal cells against the toxic effect of $\mathrm{Pb}$. Despite the presence of $\mathrm{Pb}$, EBL significantly increased the number of algal cells and their metabolite content (e.g., proteins, monosaccharides, chlorophylls, carotenes, and xanthophylls). Cultures treated concurrently with $\mathrm{EBL}$ and $\mathrm{Pb}$ were characterized by a reduction in their content of endogenous $\mathrm{Pb}, \mathrm{H}_{2} \mathrm{O}_{2}$, and malondialdehyde. Also, EBL increased the activity of catalase, ascorbate peroxidase, superoxide dismutase, glutathione reductase, and the content of ascorbate and glutathione. EBL increased the phytochelatin synthase activity, thereby enhancing the production of phytochelatins accountable for both binding and detoxification of $\mathrm{Pb}$. These results indicate the influence of EBL on the inhibitory effect of $\mathrm{Pb}$ in A. obliquus. These findings help to clarify the role of BRs in the algal adaptation to the prevailing stressful conditions.
\end{abstract}

Keywords Brassinosteroids $\cdot$ Detoxification $\cdot$ Green alga $\cdot$ Chlorophyta $\cdot$ Heavy metal

\section{Introduction}

Various environmental factors influence the life in ecosystems, and many factors affect the modification of morphological and physiological processes in plant organisms. Heavy metals contribute to a reduction of growth, decrease in the intensity of photosynthesis and content of pigments, carbohydrates, and proline, and increase in the content of malondialdehyde (MDA) or the emergence of oxidative stress in plants (Ahmad 2016). Increased content of toxic metals in the aquatic environment affects all organisms; however, the most endangered are algae, which are the main producers of aquatic ecosystems and are a valuable part of the food chain (Zhou et al. 2011; Rajamani et al. 2014). Recently, much attention has been devoted to research on substances showing the properties of plant growth regulators. One of the

Andrzej Bajguz

abajguz@uwb.edu.pl

1 University of Bialystok, Konstantego Ciolkowskiego 1J, 15-245 Bialystok, Poland phytohormone groups is brassinosteroids (BRs), which are commonly found in angiosperms, gymnosperms, algae, pteridophyte, and bryophyte at very low concentrations (Bajguz and Tretyn 2003; Stirk et al. 2013, 2014; Kanwar et al. 2017; Bajguz 2019; Zullo and Bajguz 2019). BRs significantly affect the metabolism, growth of both algae and vascular plants, and have a major role in heavy metals stress alleviation (Bajguz and Hayat 2009; Rajewska et al. 2016). BRs increase the activity of antioxidant enzymes and the content of antioxidants, protecting plants against unfavorable environmental conditions. Also, BRs significantly reduce the accumulation of heavy metals, increasing the synthesis of phytochelatins (PC) (Bajguz 2002; Behnamnia et al. 2009; Sharma et al. 2011; Arora et al. 2012).

The green alga Acutodesmus obliquus is a good model for studying the direct action of exogenous growth substances, as the reception of the hormonal, environmental stimulus and the biochemical response is not dispersed and occurs within a single cell (Bajguz and Asami 2004). Furthermore, algaethanks to the special structure of the cell wall, consisting of a fibrous structure and a high content of bound proteins with polysaccharides - can accumulate trace metals. Metal ions bond strongly with ligands to form the structure of the cell 
wall (Wang and Chen 2009; Javanbakht et al. 2013; Rajewska et al. 2016). Studies carried out on Chlorella vulgaris, Chlorella kesslerii, Scenedesmus quadricauda, Scenedesmus incrassatules, and A. obliquus proved that green algae effectively remove metals from aquatic ecosystems (Gin et al. 2002; Tripathi et al. 2006; Wilde et al. 2006; Bajguz 2010; Lourie et al. 2010; Bajguz 2011; Piotrowska-Niczyporuk et al. 2015, 2017).

One of a highly active representative of BRs is 24epibrassinolide (EBL), which is the most often subjected to plants in experiments as a growth stimulator. EBL increases the cells number and the content of pigments (chlorophylls, carotenes, and xanthophylls), monosaccharide, and protein in C. vulgaris and A. obliquus (Bajguz and Czerpak 1998; Bajguz 2000b; Talarek-Karwel et al. 2018). Moreover, previous studies confirmed the toxic effect of $\mathrm{Pb}$ ions on the unicellular green alga. Heavy metal application caused the inhibition of growth and development of A. obliquus, as well as initiation of oxidative stress (Piotrowska-Niczyporuk et al. 2015). Therefore, the role of EBL in the adaptation of A. obliquus to $\mathrm{Pb}$ stress was the main aim of this study. We tested the hypotheses that (1) EBL mitigates Pb toxicity on the algal growth and the content of pigments, protein, and monosaccharides; (2) EBL can enhance the enzymatic and nonenzymatic antioxidants level; (3) EBL involves the synthesis of PC which represent one of the mechanisms of heavy metal detoxification in plants (reduction of the endogenous level of $\mathrm{Pb})$.

\section{Materials and methods}

\section{Algal cultivation}

Acutodesmus obliquus (SAG 276-6) synchronous growth was established by the Prison and Lorenzen (1966) method. Algae were cultivated in 250-mL Erlenmeyer flasks with $100 \mathrm{~mL}$ of Bold Basal Medium (Andersen 2005; Andersen et al. 2005) at $25 \pm 0.5^{\circ} \mathrm{C}$. Fluorescent lights (photon flux $50 \mu$ mol photons $\mathrm{m}^{-2} \mathrm{~s}^{-1}$ at the surface of the tubes) were used as illumination for $16 \mathrm{~h}$. Algal cultures, initiated at $1.5 \times 10^{6}$ cells $\mathrm{mL}^{-1}$, were bubbled with air at $1 \mathrm{~L} \mathrm{~min}^{-1}$.

Previous research confirmed that the most stimulating impact of EBL (Sigma-Aldrich, USA) occurred at a concentration of $1 \mu \mathrm{M}$ after the application of six different EBL concentrations from 0.0001 to $10 \mu \mathrm{M}$ (with a multiplier of 10) on A. obliquus (Talarek-Karwel et al. 2018). Hence, $1 \mu \mathrm{M}$ EBL was chosen in this experiment. The response of $\mathrm{Pb}$ action on A. obliquus cultures was presented in Piotrowska-Niczyporuk et al. $(2015,2017)$. Thus, $\mathrm{Pb}$ at the concentrations of 0.01 and $500 \mu \mathrm{M}$ was used. Furthermore, this study shows the combined effect of EBL and $\mathrm{Pb}$ in A. obliquus cultures.

\section{Data acquisition and analytical methods}

Selected parameters were measured on the $1 \mathrm{st}, 3 \mathrm{rd}, 5$ th and 7 th days of the cultivation. The algal cultures were collected by centrifugation $(9000 \times \mathrm{g}, 10 \mathrm{~min}$; MPW-350R Med. Instruments, Poland) for biochemical analysis.

\section{Number of cells}

The cells number was counted under the Olympus CX-23 microscope using the Bürker counting chamber (Blaubrand, Germany) (Gunetti et al. 2012).

\section{Determination of monosaccharide content}

The content of monosaccharides was determined using Somogyi (1952) method. Algal pellets were homogenized in $2 \mathrm{~mL}$ of ethanol at $75{ }^{\circ} \mathrm{C}$ in bead mill $(50 \mathrm{~Hz}, 5 \mathrm{~min}$; TissueLyser LT, Qiagen, Germany) using two 5-mm zirconium balls and then centrifuged $(9000 \times g, 10 \mathrm{~min})$. After drying the supernatant, the residue was resuspended in $1 \mathrm{~mL}$ of water and desalted through a column of ion-exchange resin (Amberlite MB3). Samples were mixed with $50 \mu \mathrm{L}$ of $0.1 \mathrm{M}$ potassium ferricyanide and then $100 \mu \mathrm{L}$ of reagent $\mathrm{A}$ [0.1 M NaOH, $\left.0.1 \mathrm{~N} \mathrm{Na}_{2} \mathrm{CO}_{3} ; 1: 1(\mathrm{v} / \mathrm{v})\right]$ was added followed by water to $1000 \mu \mathrm{L}$. Then, the mixtures were heated $(10 \mathrm{~min}$, $\left.95^{\circ} \mathrm{C}\right)$ and cooled to $20^{\circ} \mathrm{C}$. The addition of reagent $\mathrm{B}(1 \mathrm{~mL})$ [0.015 M o-phenanthroline, $0.1 \mathrm{M}$ acetic acid; $1: 1(\mathrm{v} / \mathrm{v})]$ and water $(0.5 \mathrm{~mL})$ was followed by mixing and heating the content of the tubes $\left(10 \mathrm{~min}, 95^{\circ} \mathrm{C}\right)$. The absorbance values were measured at $505 \mathrm{~nm}$, after cooling to $20^{\circ} \mathrm{C}$.

\section{Determination of pigment content}

Algal pellets were homogenized in $1 \mathrm{~mL}$ of methanol $(\mathrm{MeOH})$ in bead mill $(50 \mathrm{~Hz}, 5 \mathrm{~min})$ then centrifuged $(9000 \times g, 10 \mathrm{~min})$. Supernatants were filtered through 0.45 $\mu \mathrm{m}$, PTFE, HPLC syringe cartridge filters fitted with glass fiber prefilters (A\&A Biotechnology, Poland). An Agilent 1260 Infinity Series HPLC system with Eclipse XDB $\mathrm{C}_{8}$ column $(150 \mathrm{~mm} \times 4.6 \mathrm{~mm}, 5 \mu \mathrm{m})$, maintained at $25^{\circ} \mathrm{C}$, was used. The inlet method was set as follows: mobile phase $\mathrm{A}, \mathrm{MeOH} /$ acetonitrile $(\mathrm{ACN}) / 0.25 \mathrm{M}$ aqueous pyridine $(\mathrm{pH} 5.0)$ solution $(50 / 25 / 25, \mathrm{v} / \mathrm{v} / \mathrm{v})$ and $\mathrm{B}$, $\mathrm{MeOH} / \mathrm{ACN} /$ acetone $(20 / 60 / 20, \mathrm{v} / \mathrm{v} / \mathrm{v})$. The gradient was linear from the specified initial percent solvent A $(100 \%$ in the $1 \mathrm{st} \min , 60 \%$ from the 22 nd $\min , 5 \%$ from the 28 th min, $5 \%$ from the 38 th $\min , 100 \%$ in the 40 th $\mathrm{min}$ ). Flow rates were adjusted to keep back pressure below 180 bar (1 $\mathrm{mL} \mathrm{min}^{-1}$ ) (Zapata et al. 2000). For the analytical data integration, ChemStation software was used. 


\section{Determination of lead content}

Heavy metal level was determined by flame atomic absorption spectrometry using a Solaar M6 (Thermo Electron Corporation, UK) spectrometer with deuterium background correction system. Initially, algal cultures were centrifuged (9000g, $10 \mathrm{~min})$ and the suspension was dried $\left(105^{\circ} \mathrm{C}, 6 \mathrm{~h}\right)$. Then, samples were mineralized in $200 \mu \mathrm{L}$ of $65 \%$ nitric acid. Finally, the absorbance was measured in air-acetylene flame with $0.5 \mathrm{~nm}$ spectral bandpass at $217 \mathrm{~nm}$ (PiotrowskaNiczyporuk et al. 2015).

\section{Determination of $\mathrm{H}_{2} \mathrm{O}_{2}$ and malondialdehyde contents}

To determine $\mathrm{H}_{2} \mathrm{O}_{2}$ and MDA, algal pellets were homogenized in $1 \mathrm{~mL}$ of $5 \%(\mathrm{w} / \mathrm{v})$ trichloroacetic acid in bead mill (50 Hz, $5 \mathrm{~min})$. Then, the homogenates were centrifuged (9000g, $15 \mathrm{~min}, 3{ }^{\circ} \mathrm{C}$ ). To measure $\mathrm{H}_{2} \mathrm{O}_{2}$ level, supernatant was mixed with reaction mixture $(2.5 \mathrm{mM}$ potassium phosphate buffer [ $\mathrm{pH} 7.0]$ and $500 \mathrm{mM}$ potassium iodide), and the absorbance was measured at $390 \mathrm{~nm}$ (Velikova et al. 2000). For determination of MDA, supernatant mixed with reaction mixture $[0.5 \%(\mathrm{w} / \mathrm{v})$ thiobarbituric acid (TBA) in 20\% TCA] was incubated $\left(95^{\circ} \mathrm{C}, 20 \mathrm{~min}\right)$, then a reaction was terminated by placing vials on ice. Absorbance was measured at $532 \mathrm{~nm}$. The nonspecific absorption at $600 \mathrm{~nm}$ was subtracted from the absorbance data. The amount of MDA-TBA complex was calculated using the extinction coefficient equal $155 \mathrm{mM}^{-1}$ $\mathrm{cm}^{-1}$ (Cakmak and Horst 1991).

\section{Determination of protein and antioxidant levels}

For estimation of the content of protein and the activities of antioxidant enzymes, algal pellets were homogenized in $50 \mathrm{mM}$ phosphate buffer ( $\mathrm{pH}$ 7.0), $1 \mathrm{mM}$ ethylenediaminetetraacetic acid (EDTA), $1 \mathrm{mM}$ phenylmethanesulfonylfluoride, $0.5 \%$ (v/v) Triton X-100, and 2\% (w/v) polyvinylpyrrolidone (PVP)-30 in bead mill (50 Hz, $5 \mathrm{~min}$ ). For ascorbate peroxidase determination, $0.5 \mathrm{mM}$ ascorbate was added to the extraction buffer. Then, the homogenate was centrifuged $\left(9000 \times g, 15 \mathrm{~min}, 3{ }^{\circ} \mathrm{C}\right)$. The supernatant was further used for quantitative analysis of antioxidant enzymes and protein.

The protein content was estimated following the Bradford (1976) method using bovine serum albumin as a standard. Supernatant $(100 \mu \mathrm{L})$ and $3 \mathrm{~mL}$ of the Bradford reagent $[0.01 \%(\mathrm{w} / \mathrm{v})$ Coomassie Brilliant Blue G-250, 4.7\% (w/v) ethanol, $8.5 \%(\mathrm{w} / \mathrm{v}) \mathrm{H}_{3} \mathrm{PO}_{4}$ ] were transferred to assay tube. Then, the absorbance at $595 \mathrm{~nm}$ was measured after $5 \mathrm{~min}$ and before $1 \mathrm{~h}$ to check the stability of the protein dye complex.

The activity of ascorbate peroxidase (APX) was measured according to Nakano and Asada (1981) method by monitoring the rate of absorbance at $290 \mathrm{~nm}$ using the extinction coefficient equal $2.8 \mathrm{mM}^{-1} \mathrm{~cm}^{-1}$. The $3 \mathrm{~mL}$ reaction mixture contained $50 \mathrm{mM}$ potassium phosphate buffer $(\mathrm{pH} \mathrm{7.0)}$, $0.5 \mathrm{mM}$ ascorbate, $1 \mathrm{mM} \mathrm{H}_{2} \mathrm{O}_{2}$, and $100 \mu \mathrm{L}$ enzyme extract $\left(3 \mathrm{~min}, 25^{\circ} \mathrm{C}\right.$ ). The enzyme activity was estimated as the amount of enzyme that oxidizes $1 \mu \mathrm{M}$ of ascorbate consumed per milligram of soluble protein per minute.

The activity of sodium dismutase (SOD) was tested by registering the inhibition of photochemical reduction of nitroblue tetrazolium (NBT) at $560 \mathrm{~nm}$. For total SOD assay, $3 \mathrm{~mL}$ reaction mixture contained $50 \mathrm{mM}$ sodium carbonate (pH 10.2), $24 \mu \mathrm{M}$ NBT, 0.1 mM EDTA, 1 mM hydroxylamine, $0.03 \%(\mathrm{v} / \mathrm{v})$ Triton $\mathrm{X}-100$, and $70 \mu \mathrm{L}$ enzyme extract. The amount causing $50 \%$ inhibition of the photochemical reduction of NBT was assumed as one unit of SOD per milligram protein (Beauchamp and Fridovich 1971).

Method of Aebi (1984) was used for determination of the activity of catalase (CAT) by monitoring the rate of absorbance of $\mathrm{H}_{2} \mathrm{O}_{2}$ at $240 \mathrm{~nm}$ for $0.5 \mathrm{~min}$ at $25^{\circ} \mathrm{C}$. The $3 \mathrm{~mL}$ reaction mixture contained $50 \mathrm{mM}$ potassium phosphate buffer (pH 7.0), $15 \mathrm{mM} \mathrm{H}_{2} \mathrm{O}_{2}$, and $100 \mu \mathrm{L}$ enzyme extract. One unit of CAT activity was defined as the amount of enzyme that decomposes $1 \mu \mathrm{M}$ of $\mathrm{H}_{2} \mathrm{O}_{2}$ per milligram of soluble protein per minute.

The activity of glutathione reductase (GR) was determined following the procedure of Schaedle and Bassham (1977). The $3 \mathrm{~mL}$ reaction mixture contained $50 \mathrm{mM}$ potassium phosphate buffer ( $\mathrm{pH}$ 7.6), $1 \mathrm{mM}$ oxidized glutathione, $0.5 \mathrm{mM}$ EDTA, $0.1 \mathrm{mM}$ reduced NADPH, and $100 \mu \mathrm{L}$ enzyme extract. The reaction was started using $0.1 \mathrm{mM} \mathrm{NADPH}$ at 25 ${ }^{\circ} \mathrm{C}$. The GR activity was defined from the rate of NADPH oxidation as measured by the decrease of absorbance at $340 \mathrm{~nm}$ (the extinction coefficient equal $6.2 \mathrm{mM}^{-1} \mathrm{~cm}^{-1}$ ).

Determination of total ascorbate was tested by Kampfenkel et al. (1995) method. Algal pellets were homogenized in $2 \mathrm{~mL}$ $5 \%(\mathrm{w} / \mathrm{v}) \mathrm{TCA}$ in bead mill $(50 \mathrm{~Hz}, 5 \mathrm{~min})$ and then centrifuged $(9000 \times g, 10 \mathrm{~min})$. The supernatant was transferred to a reaction mixture [10 $\mathrm{mM}$ DTT, $0.2 \mathrm{M}$ phosphate buffer $(\mathrm{pH}$ 7.4), $0.5 \% \mathrm{~N}$-ethylmaleimide, $10 \%$ TCA, $42 \% \mathrm{H}_{3} \mathrm{PO}_{4}, 4 \%$ 2,2'-bipyridyl and $3 \% \mathrm{FeCl}_{3}$ ]. After shaking, a mixture was incubated (40 $\mathrm{min}, 42{ }^{\circ} \mathrm{C}$ ) and the absorbance value was recorded at $525 \mathrm{~nm}$.

\section{Determination of glutathione and phytochelatin levels}

For determination of GSH and different types of PC, HPLC analysis according to procedure of Le Faucheur et al. (2006) and Scheidegger et al. (2011) was used. The algal cultures were collected by centrifugation $(9000 \times g, 10 \mathrm{~min})$ and samples were homogenized with $0.1 \%$ trifluoroacetic acid $(\mathrm{w} / \mathrm{v})$ with $6.3 \mathrm{mM}$ diethylenetriaminepentaacetic acid in bead mill (50 Hz, $5 \mathrm{~min}$ ), after centrifugation supernatant and derivatized (30 min, $45^{\circ} \mathrm{C}$, dark) using monobromobimane $(\mathrm{mBBr})$. HPLC analysis was performed using an Agilent Technologies 1260 Infinity series system consisting of the 
1260 Infinity Agilent Quaternary pump G1311B, 1260 Infinity Fluorescence Detector G1321B, 1260 Infinity ALS G1329B Automated Sample Injector, 1290 Infinity Autosampler Thermostat G1330B, and a thermostatted column oven 1290 Infinity TCC G1316C. The system was controlled by Agilent OpenLab ChemStation software. Glutathione (GSH) and PC were separated with a Cosmosil Packed Column $\mathrm{C}_{18}$-MS-II $(4.6 \mu \mathrm{m} \times 250 \mathrm{~mm}, 5 \mu \mathrm{m})$ and kept at $37{ }^{\circ} \mathrm{C}$ with a column oven. Samples $(25 \mu \mathrm{L})$ were injected and run in a gradient: $0-15 \mathrm{~min}, 12-25 \%(\mathrm{v} / \mathrm{v})$ $\mathrm{MeOH} ; 15-29$ min, 25-35\% (v/v) MeOH; 29-50 min, 35$50 \%(\mathrm{v} / \mathrm{v}) \mathrm{MeOH}$. The column was then cleaned with $100 \%$ $(\mathrm{v} / \mathrm{v}) \mathrm{MeOH}$ and reequilibrated in $12 \%(\mathrm{v} / \mathrm{v}) \mathrm{MeOH}$. Excitation wavelength was $380 \mathrm{~nm}$; emission wavelength was $470 \mathrm{~nm}$. The retention time of GSH and PC was verified by their standards (AnaSpec, EGT Corporate, USA). To estimate the content of GSH and PC, a calibration curve (standards vs. resulting peak area) was prepared.

\section{Determination of phytochelatin synthase activity}

The activity of phytochelatin synthase (PCS) was determined by Finkemeier et al. (2003) method. Hence, $50 \mathrm{~mL}$ of algal culture was centrifuged $(9000 \times \mathrm{g}, 10 \mathrm{~min})$ and $\mathrm{ex}-$ tracted in $2 \mathrm{~mL}$ of buffer containing $20 \mathrm{mM}$ HEPES-NaOH, $\mathrm{pH} 7.5,10 \mathrm{mM} \beta$-mercaptoethanol, $100 \mu \mathrm{M} \mathrm{CdSO}_{4}, 20 \%$ $(\mathrm{w} / \mathrm{v})$ glycerol, and $100 \mathrm{mg} \mathrm{mL}^{-1}$ PVP using bead mill (50 $\mathrm{Hz}, 5 \mathrm{~min})$. After centrifugation $(9000 \times \mathrm{g}, 10 \mathrm{~min})$, the sample contained $400 \mu \mathrm{L}$ extract and $100 \mu \mathrm{L}$ reaction buffer (25 mM GSH, $100 \mu \mathrm{M} \mathrm{CdSO}_{4}, 10 \%(\mathrm{w} / \mathrm{v})$ glycerol, $250 \mathrm{mM}$ HEPES-NaOH, and $\mathrm{pH}$ 8.0) and protease inhibitor mix "Complete" (Sigma-Aldrich) was incubated (90 min, $35{ }^{\circ} \mathrm{C}$ ). Reaction was stopped by addition of $125 \mu \mathrm{L} 20 \%$ (w/v) TCA. After derivatization with $\mathrm{mBBr}$, PCS activity was measured using HPLC method as described above for PC determination.

\section{Statistics}

All experiments were repeated five times $(n=5)$. The $\mathrm{R}$ language (R Core Team 2019) was used to perform the statistical analysis of the results, which were preliminarily described as mean \pm standard deviation. The data were tested $(\alpha=0.05)$ for normality [Shapiro-Wilk test - "stats" package (R Core Team 2019)] and homogeneity of variances [Levene's test - "car" package (Fox and Weisberg 2011)]. One-way ANOVA ("stats" package) followed by the Scott-Knott's post-hoc test ["laercio" package (da Silva 2010)] was applied to check the existence of statistically significant differences between means $(p<0.05)$. The data were visualized as plots with the help of "ggplot2" package.

\section{Results}

\section{The number of cells and the content of protein and monosaccharides}

Among the tested conditions, applying $1 \mu \mathrm{M}$ EBL alone had the most stimulating effect on the number of A. obliquus cells, as well as on the protein and monosaccharides content (Fig. $1 \mathrm{a}, \mathrm{c}, \mathrm{d})$. Exposure to $0.01 \mu \mathrm{M} \mathrm{Pb}$ did not cause changes in the number of cells and the content of the studied A. obliquus metabolites. The inhibition of growth and a reduction in the content of all the above parameters was detected in A. obliquus cultures exposed to $500 \mu \mathrm{M} \mathrm{Pb}$. EBL alleviated the toxic effect of $\mathrm{Pb}$. The biggest (80-90\%) raise was reported on the 5 th day of cultivation relative to the $\mathrm{Pb}$ alone, after the application of $1 \mu \mathrm{M}$ EBL and the lower concentration of $\mathrm{Pb}(0.01 \mu \mathrm{M})$. In the presence of the highest $\mathrm{Pb}$ concentration $(500 \mu \mathrm{M})$ mixed with EBL, a slight increase was observed for the number of cells (by 10-40\%), protein level (9-54\%), and monosaccharides level (10-40\%) relative to the $500 \mu \mathrm{M} \mathrm{Pb}$ exposure. However, the level of these metabolites was lower than in the control condition. Moreover, the growth and level of studied A. obliquus metabolites increased together with the increase in the exposure time to EBL and/or $\mathrm{Pb}$ reaching the maximum on the 5th day of cultivation, except for $500 \mu \mathrm{M} \mathrm{Pb}$ and $500 \mu \mathrm{M} \mathrm{Pb}$ mixed with $1 \mu \mathrm{M} \mathrm{EBL}$. A minor decrease in the parameters with respect to the 5th day was noted on the last day.

\section{The content of lead}

As shown in Fig. 1 b, the intracellular $\mathrm{Pb}$ level in green alga was associated with the concentration of heavy metal, and this increased proportionally with increasing time of exposure. Algae exposed to $500 \mu \mathrm{M} \mathrm{Pb}$ on the last day exhibited the highest metal ion accumulation; however, the addition of EBL resulted in a decline in the metal accumulation by $15-44 \%$ in relation to $\mathrm{Pb}$ alone. On the other hand, the content of $\mathrm{Pb}$ was similar to the control during the whole period of cultivation under the influence of EBL and/or $0.01 \mu \mathrm{M} \mathrm{Pb}$.

\section{The content of photosynthetic pigments}

The influence of $1 \mu \mathrm{M}$ EBL on the level of chlorophyll $a$ and $b$, carotenes ( $\alpha$-carotene and $\beta$-carotene), oxygen-poor xanthophylls (zeaxanthin, lutein, cryptoxanthin), and oxygen-rich xanthophylls (neoxanthin, violaxanthin, astaxanthin) was examined after treatment with 0.01 and $500 \mu \mathrm{M} \mathrm{Pb}$ (Table 1). In cultures treated with $\mathrm{Pb}$, a remarkable loss in photosynthetic pigments content was reported. The highest inhibitory effect of $\mathrm{Pb}$ was observed at a concentration of $500 \mu \mathrm{M}$. In contrast, $0.01 \mu \mathrm{M} \mathrm{Pb}$ had a similar effect on the pigment content in A. obliquus cells compared with the control. The reduction of 
Cultivation time in day:
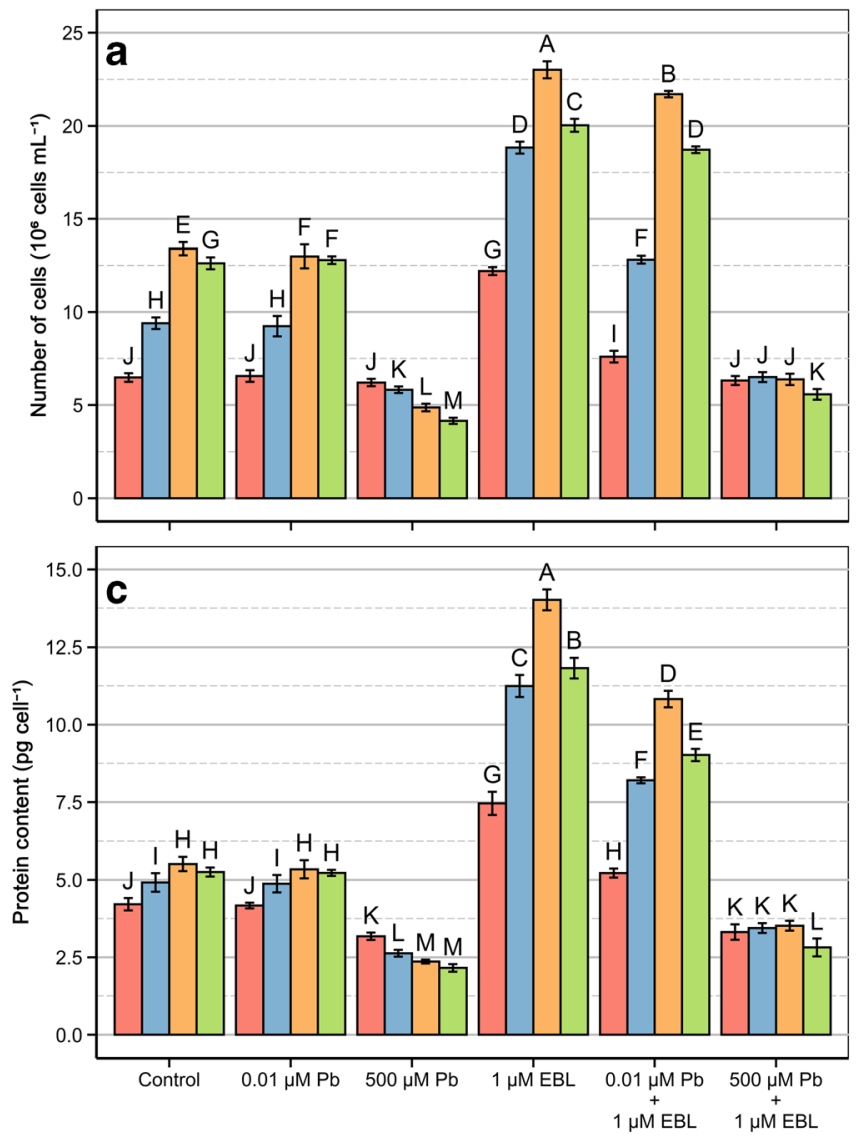

Fig. 1 The effect of lead and/or 24-epibrassinolide (EBL) on the number of cells (a) and the content of endogenous lead (b), protein (c), and monosaccharides (d) in Acutodesmus obliquus. Bars show the mean ( $n$

the studied photosynthetic pigments in algae treated with $\mathrm{Pb}$ was ameliorated by the addition of $1 \mu \mathrm{M}$ EBL. The maximum increase of selected pigments was $72 \%$ for chlorophyll $a, 52 \%$ for chlorophyll $b, 24 \%$ for $\beta$-carotene, $61 \%$ for neoxanthin, $19 \%$ for astaxanthin, and $88 \%$ for zeaxanthin on the 5 th day under $0.01 \mu \mathrm{M} \mathrm{Pb}$ and $1 \mu \mathrm{M}$ EBL relative to $0.01 \mu \mathrm{M} \mathrm{Pb}$ alone. In turn, the greatest shares of EBL on the enhancement in the violaxanthin, lutein, and cryptoxanthin content was reported $(84 \%, 68 \%, 117 \%$, respectively) in alga treated with $500 \mu \mathrm{M} \mathrm{Pb}$ and $1 \mu \mathrm{M} \mathrm{EBL}$ on the 5th day with respect to the $500 \mu \mathrm{M} \mathrm{Pb}$, except for $\alpha$-carotene, where the maximum increase was noticed on the 7th day. Among all tested combinations, exposure to EBL alone caused the greatest increase in photosynthetic pigments content.

\section{The content of $\mathrm{H}_{2} \mathrm{O}_{2}$ and malondialdehyde}

$\mathrm{Pb}$ at the concentrations of 0.01 and $500 \mu \mathrm{M}$ produced an increase in oxidative stress in A. obliquus cells (Fig. 2a, b), due to the noticeably high $\mathrm{H}_{2} \mathrm{O}_{2}$ and accelerated lipid peroxidation process (expressed as a level of MDA) related with the rise in the metal concentration. The application of $1 \mu \mathrm{M}$ EBL
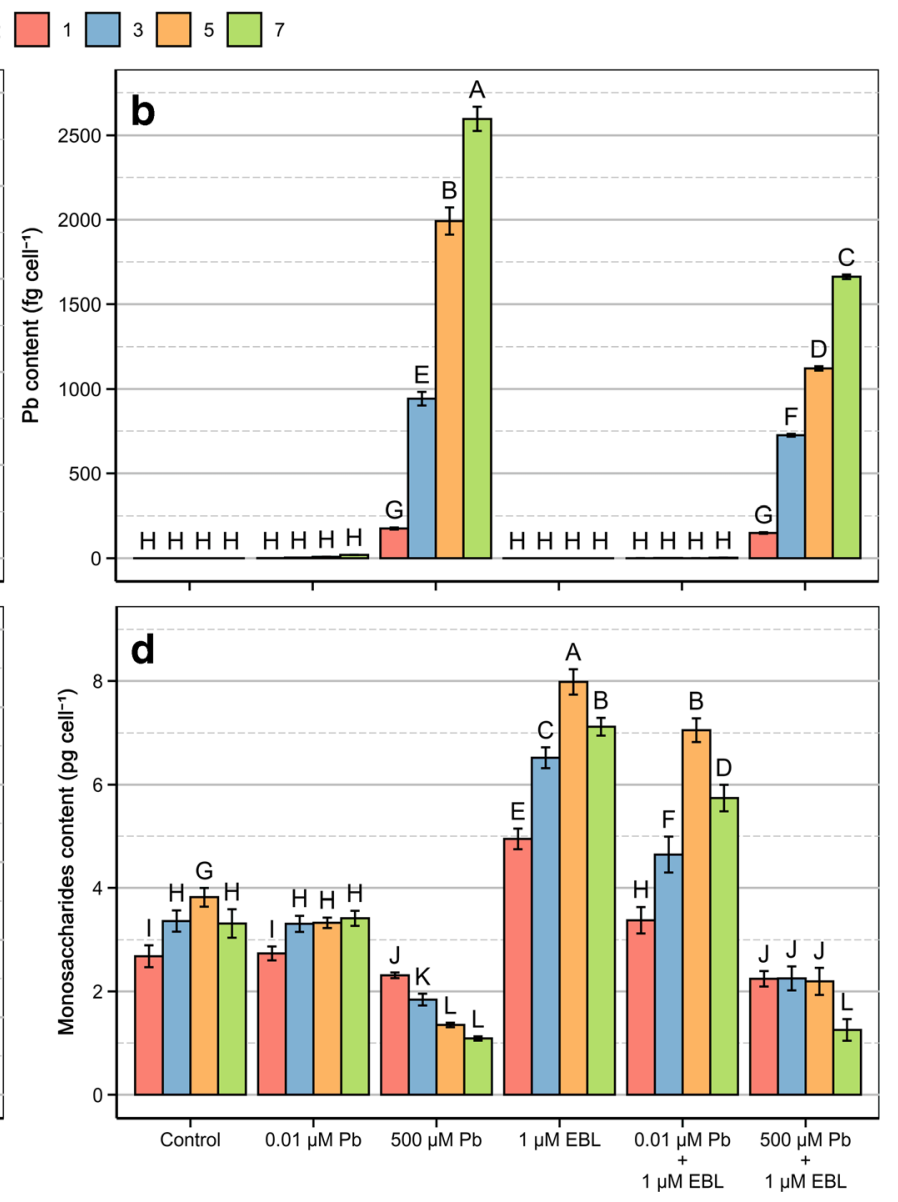

$=5$ ) with standard deviation. Means with the same letters are not significantly different $(p \geq 0.05)$ according to Scott-Knott's post-hoc test. Data were grouped by the day of cultivation and treatment for each pigment

limited the $\mathrm{H}_{2} \mathrm{O}_{2}$ level and MDA content after the application of $\mathrm{Pb}$. The biggest reduction in $\mathrm{H}_{2} \mathrm{O}_{2}$ (by $60 \%$ ) and MDA (by $61 \%$ ) contents by EBL were recorded under $0.01 \mu \mathrm{M} \mathrm{Pb}$ on the 5th day, relative to the $0.01 \mu \mathrm{M} \mathrm{Pb}$ alone. EBL minimized the level of these compounds at $500 \mu \mathrm{M} \mathrm{Pb}$ to a lesser extent. The content of $\mathrm{H}_{2} \mathrm{O}_{2}$ and MDA was smaller (by 20\%) than in the A. obliquus treated only with $500 \mu \mathrm{M} \mathrm{Pb}$, but higher than in control by $29 \%$ and $37 \%$, respectively.

\section{The level of antioxidants}

Under $0.01 \mu \mathrm{M} \mathrm{Pb}$ exposure, a slight increase in the activity of antioxidants in algal cultures, especially on the 5th day of the experiment, was observed (Figs. 2c-f and Fig. 5a). In turn, the activity of the antioxidant system was limited after the application of $500 \mu \mathrm{M} \mathrm{Pb}$. EBL greatly stimulated the level of antioxidants. In the case of $1 \mu \mathrm{M} \mathrm{EBL}$, we detected a greater than twofold increase in ascorbate content and CAT and APX activities, as well as a doubling in SOD activity. However, hormone alone had a smaller impact on GR activity and GSH content. EBL mixed with $0.01 \mu \mathrm{MPb}$ was found to have a remarkable stimulating effect on the antioxidant system. On 
.

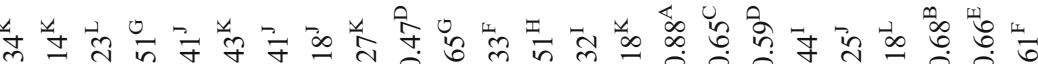

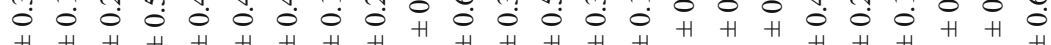

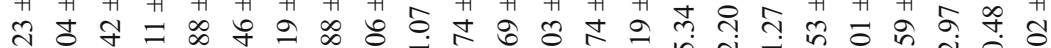

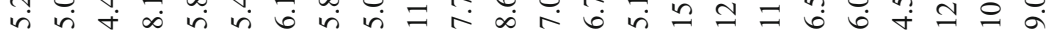

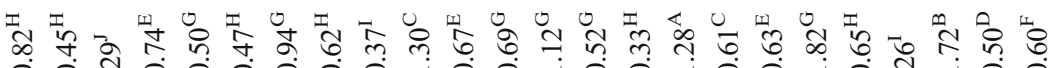

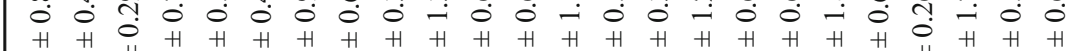

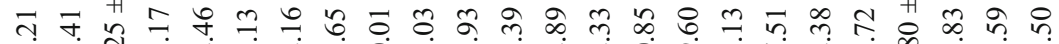

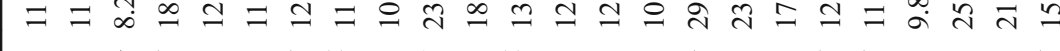
in

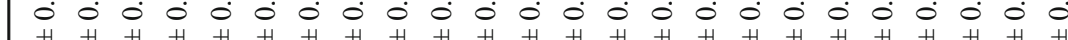

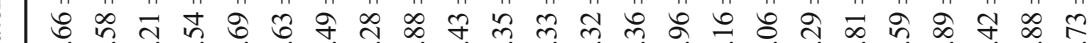

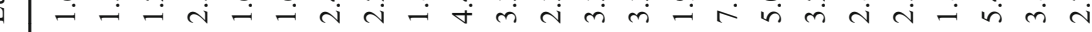

ॠ

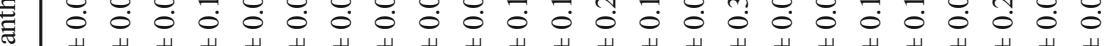

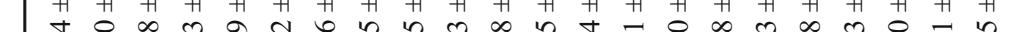

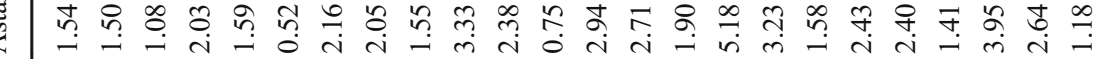

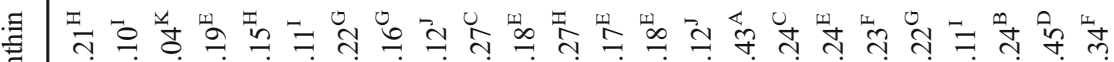

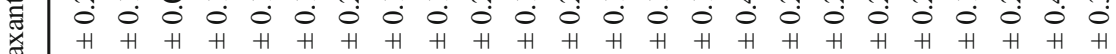

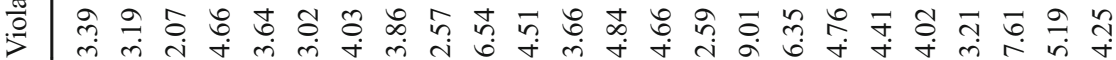

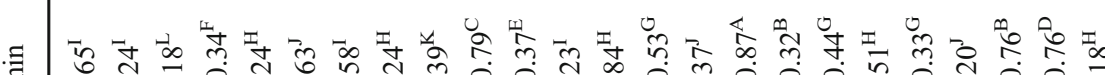
至 政

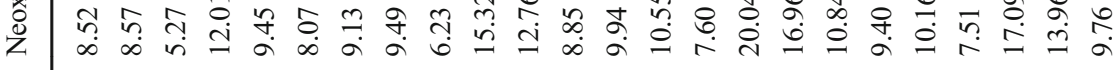

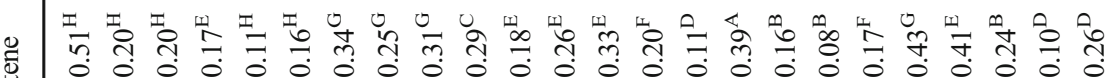
H $\begin{array}{lllllllllllllllll} & 0\end{array}$

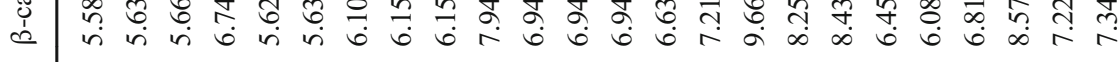

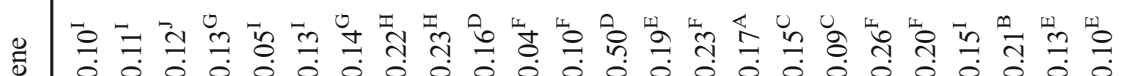
党

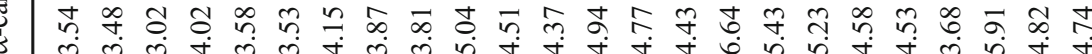

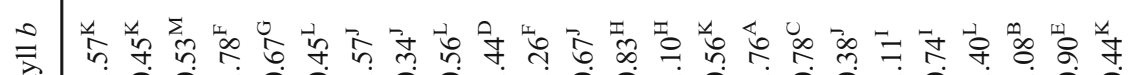

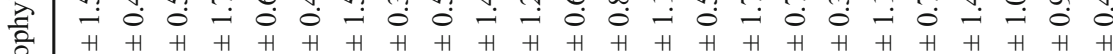
하의

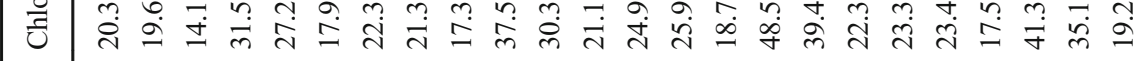

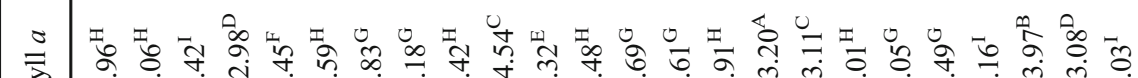

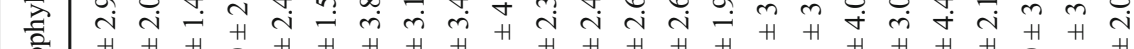

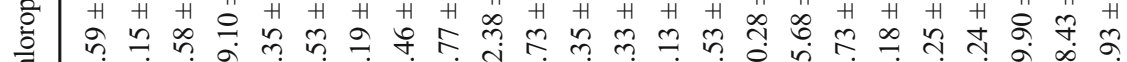

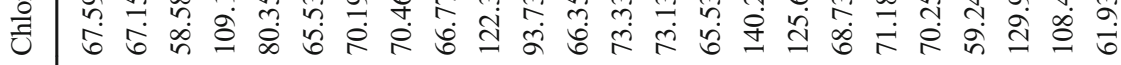

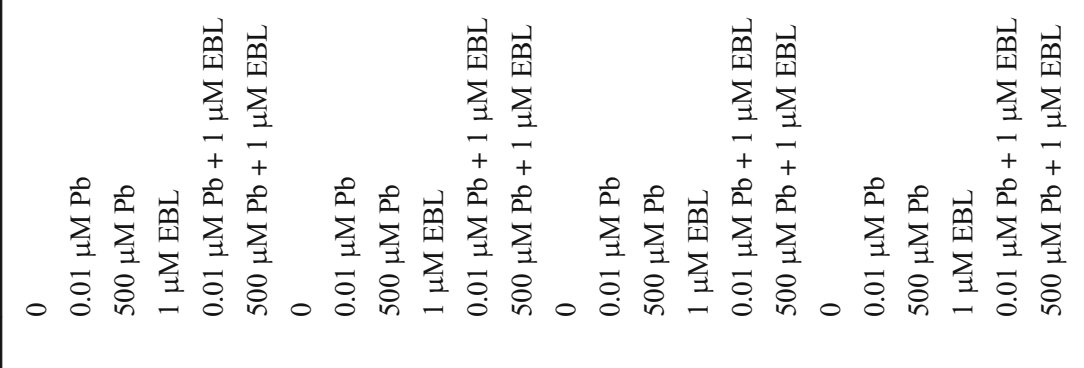

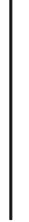


Cultivation time in day
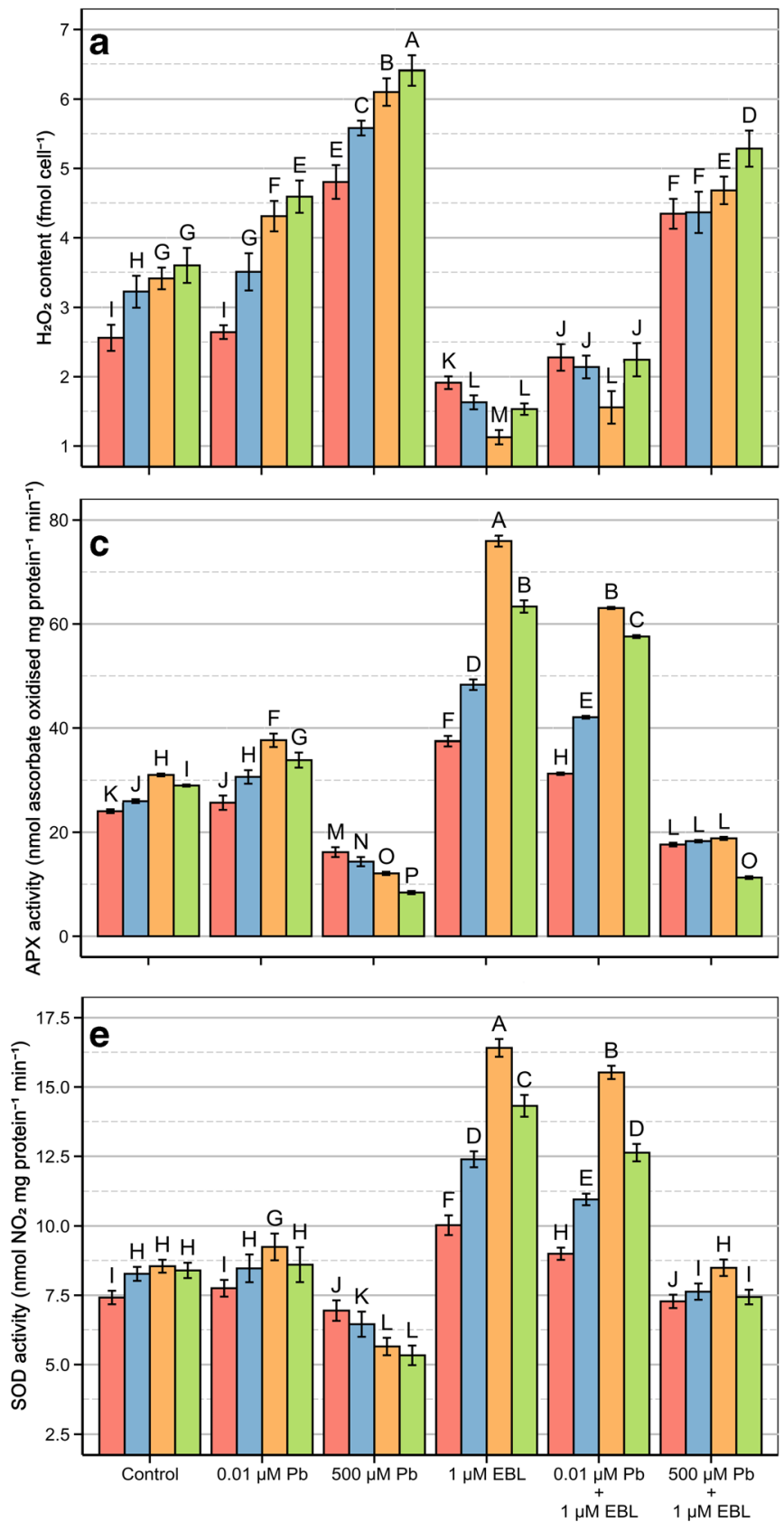

Fig. 2 The effect of lead and/or 24-epibrassinolide (EBL) on the content of $\mathrm{H}_{2} \mathrm{O}_{2}$ (a), malondialdehyde (MDA, b), the activity of ascorbate peroxidase (APX, c), ascorbate content (d), the activity of superoxide dismutase (SOD, e) and catalase (CAT, $\mathbf{f}$ ) in Acutodesmus obliquus. Bars

the 5th day, the activity of SOD, APX, CAT, and GR, and the content of ascorbate and GSH increased by 70, 80, 75, 80, 89, and $72 \%$, respectively, compared with the heavy metal alone. The application of $500 \mu \mathrm{M} \mathrm{Pb}$ caused a major reduction of the antioxidants level; however, co-application of EBL did not lead to any improvement. Treatment of the A. obliquus cultures with $500 \mu \mathrm{M} \mathrm{Pb}$ and EBL was associated with reduced GSH content. However, the stimulation of the GSH content by
${ }^{1} \square \square^{3} \square 7$
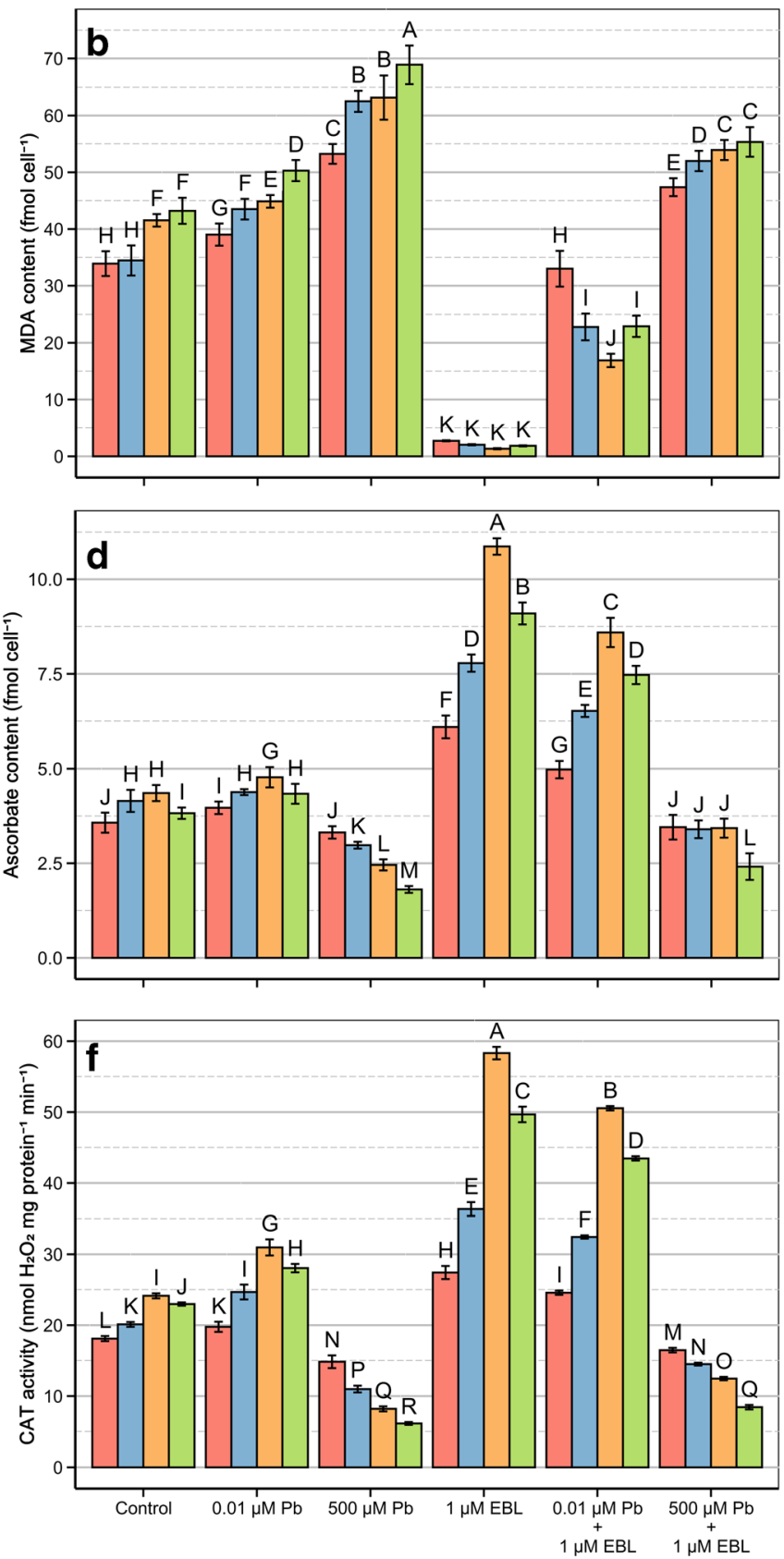

show the mean $(n=5)$ with standard deviation. Means with the same letters are not significantly different ( $p \geq 0.05)$ according to Scott-Knott's post-hoc test. Data were grouped by the day of cultivation and treatment for each pigment

$20-35 \%$ in algal cultures in relation to the control was noticed during the whole study under the highest $\mathrm{Pb}$ concentration.

\section{The content of phytochelatin}

Treatment of $A$. obliquus cells with $\mathrm{Pb}$ and/or EBL affects $\mathrm{PC}_{2}, \mathrm{PC}_{3}, \mathrm{PC}_{4}$, and $\mathrm{PC}_{5}$ synthesis (Fig. 3a-d). The highest $\mathrm{PC}_{2-5}$ level was detected under $1 \mu \mathrm{M}$ EBL exposure, and the 
Cultivation time in day:
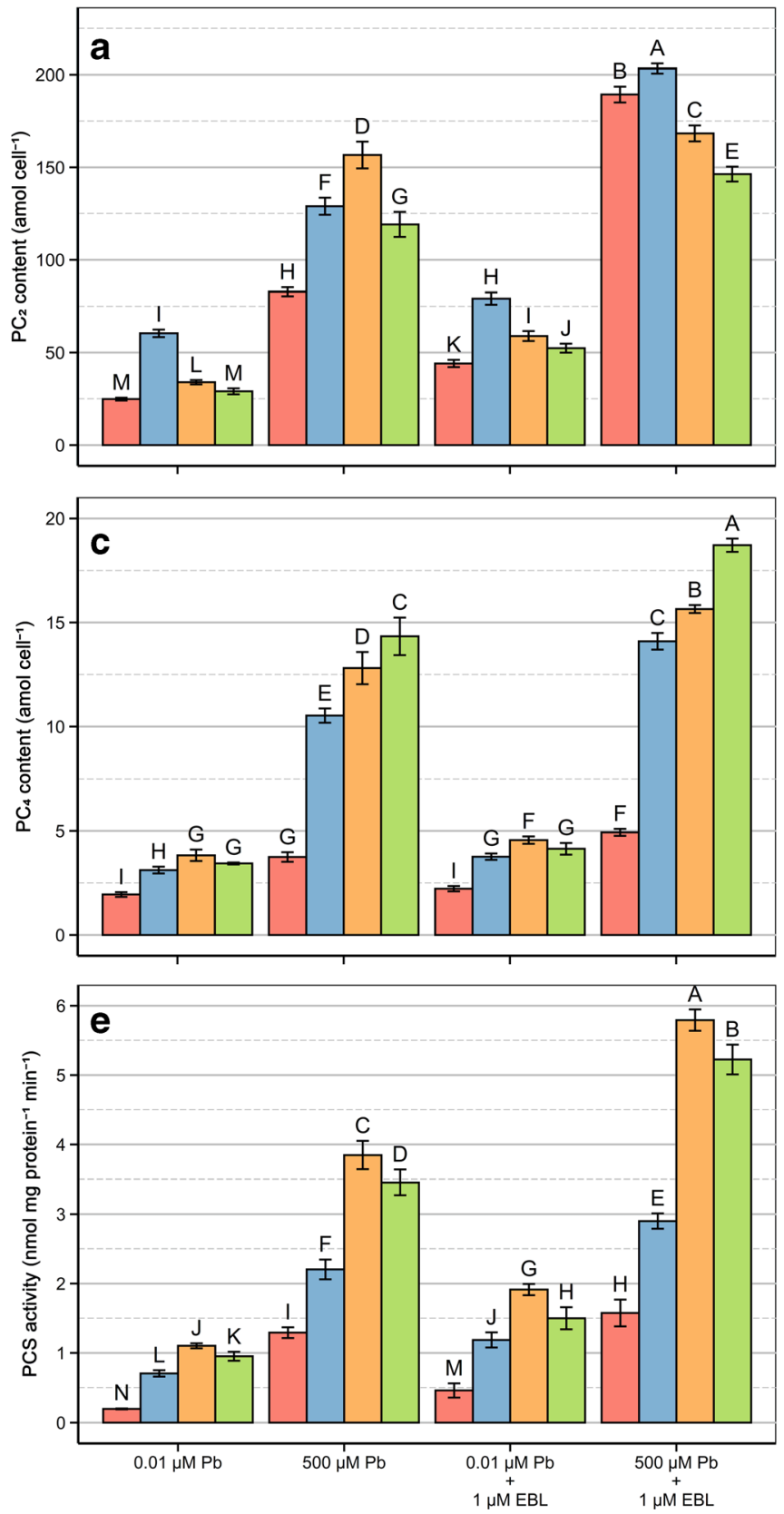

Fig. 3 The effect of lead and/or 24-epibrassinolide (EBL) on the content of phytochelatins $\left(\mathrm{PC}_{2}, \mathbf{a} ; \mathrm{PC}_{3}, \mathbf{b} ; \mathrm{PC}_{4}, \mathbf{c} ; \mathrm{PC}_{5}, \mathbf{d}\right)$ and the activity of phytochelatins synthase (PCS, e) in Acutodesmus. Bars show the mean ( $n$

lowest after application of $0.01 \mu \mathrm{M} \mathrm{Pb}$, but $500 \mu \mathrm{M} \mathrm{Pb}$ caused the inhibition of $\mathrm{PC}_{2-5}$ synthesis. The level of $\mathrm{PC}_{2}$ and $\mathrm{PC}_{3}$ in algal cells increased until the third day, and then the content of both peptides reduced gradually. On the 3rd day of cultivation, the highest content of $\mathrm{PC}_{2}$ and $\mathrm{PC}_{3}$ (fourfold rise) was recorded in cultures grown in the presence of $1 \mu \mathrm{M} \mathrm{EBL}$ and $\mathrm{Pb}$. In the case of longer oligomers of $\mathrm{PC}$, the highest content of $\mathrm{PC}_{4}$ and $\mathrm{PC}_{5}$ (an almost fourfold increase compared with the control group) was noted in cells exposed to $1 \mu \mathrm{M} \mathrm{EBL}$ and $\mathrm{Pb}$ on the last day. Under heavy metal exposure, a significant impact
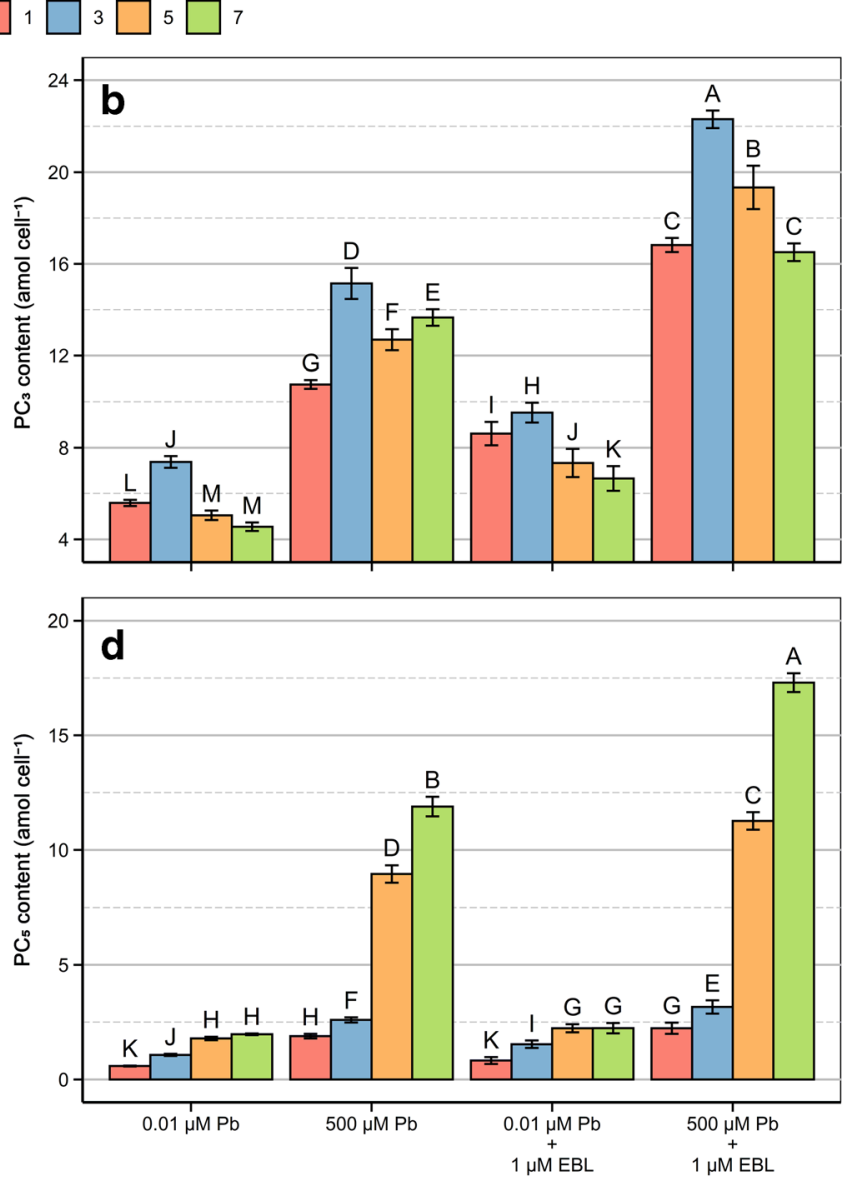

$=5$ ) with standard deviation. Means with the same letters are not significantly different $(p \geq 0.05)$ according to Scott-Knott's post-hoc test. Data were grouped by the day of cultivation and treatment for each pigment

on PC synthesis was also observed. After the application of $0.01 \mu \mathrm{M} \mathrm{Pb}$, the content of $\mathrm{PC}_{2}$ tripled on the 5 th day and $\mathrm{PC}_{4}$ on the 7th day. Moreover, under the above conditions, the content of $\mathrm{PC}_{3}$ and $\mathrm{PC}_{5}$ doubled on the 3 th and 7 th days, respectively. The weakest effect on the $\mathrm{PC}_{2-5}$ content was noted in the whole period of the experiment when the highest concentration of $\mathrm{Pb}(500 \mu \mathrm{M})$ was used. During 7 days of cultivation, $\mathrm{PC}_{2}$ had the highest share among $\mathrm{PC}$ (74-89\%) (Fig. 4). The percentage shares of $\mathrm{PC}_{3}, \mathrm{PC}_{4}$, and $\mathrm{PC}_{5}$ were $7-$ $17 \%, 3-9 \%$, and $1-9 \%$, respectively. 


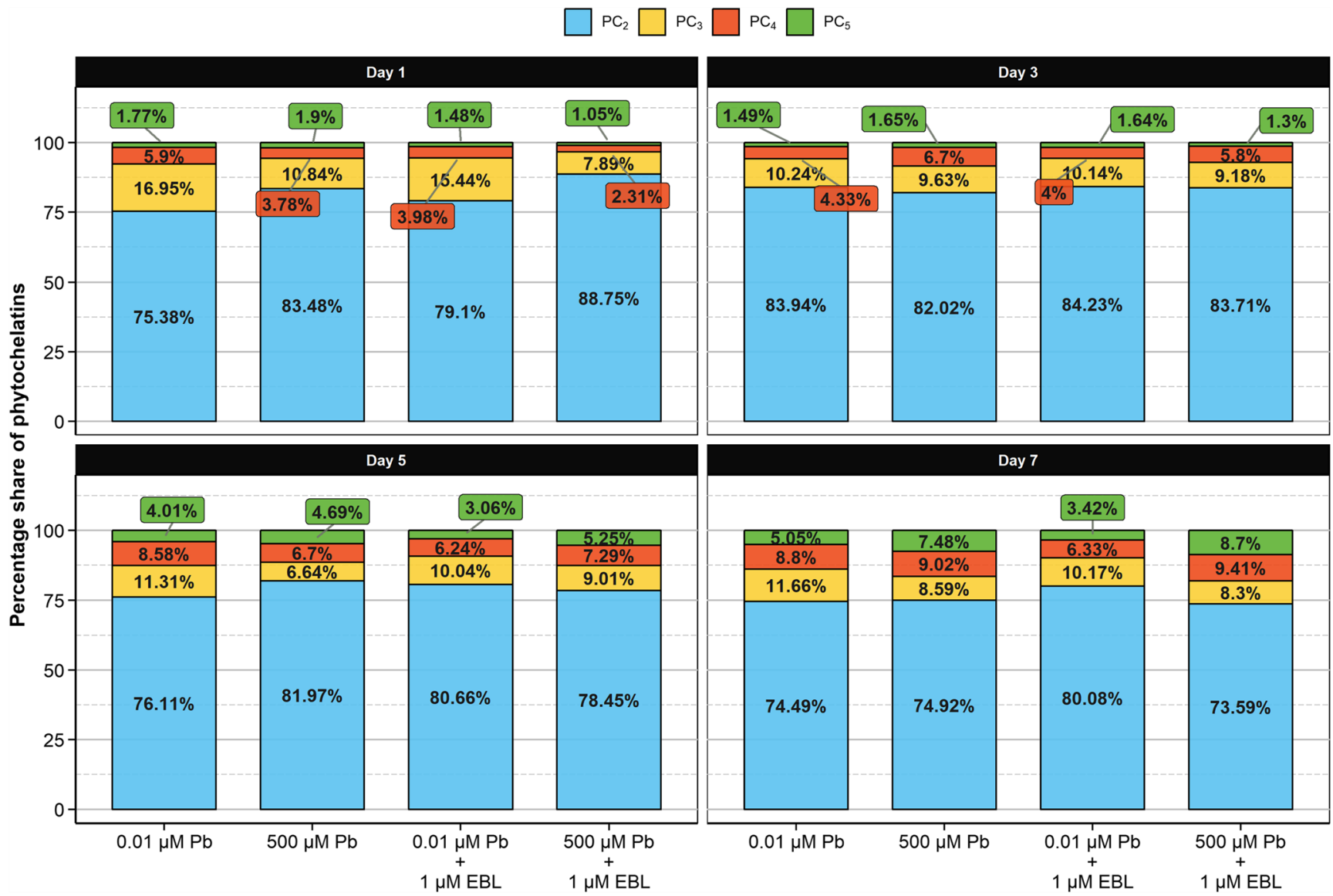

Fig. 4 Percentage share of phytochelatins in Acutodesmus obliquus treated with lead and 24-epibrassinolide (EBL)

\section{The activity of phytochelatin synthase}

The effect of $1 \mu \mathrm{M}$ EBL and $0.01 \mu \mathrm{M}$ or $500 \mu \mathrm{M} \mathrm{Pb}$ on the activity of PCS in A. obliquus cultures was examined (Fig. $3 e)$. The stimulating effect of BR on the enzyme activity was observed from the 1 st to 7 th days and peaked on the 5 th day in $\mathrm{Pb}$-treated cultures. Algae treated with $\mathrm{Pb}$ alone showed a weaker PCS activity increase than in cultures treated with $\mathrm{EBL}$ and $\mathrm{Pb}$. The highest, almost sixfold increase in the activity of PCS in A. obliquus cells, relative to the control, was exerted at a concentration of $1 \mu \mathrm{M}$ EBL and $\mathrm{Pb}$. Application of $0.01 \mu \mathrm{M}$ and $500 \mu \mathrm{M} \mathrm{Pb}$ produced a fourfold and doubling in the PCS activity, respectively, relative to untreated algae. The present study shows that both EBL and $\mathrm{Pb}$ had a large influence on the enzyme activity during PC synthesis.

\section{Discussion}

The obtained results suggest that the biosorption of $\mathrm{Pb}$ by A. obliquus is associated with a variety of biochemical changes that contribute to heavy metal tolerance. $\mathrm{Pb}$ caused an inhibition of algal growth (Fig. 1a) and decrease in the content of pigments (Table 1), protein (Fig. 1c), and monosaccharides
(Fig. 1d). In addition, a stimulating effect of $\mathrm{Pb}$ in the formation of $\mathrm{H}_{2} \mathrm{O}_{2}$, together with increased lipid peroxidation, was observed (Fig. 2a, b), thereby demonstrating the influence of metal on the initiation of oxidative stress. $\mathrm{Pb}$ at low concentration $(0.01 \mu \mathrm{M})$ increased the level of antioxidants (Figs. 2 and 5). Dao and Beardall (2016) confirmed that Scenedesmus sp. was very sensitive to $0.03-0.87 \mathrm{nM} \mathrm{Pb}$ with a continuous decline in growth rate. On the other hand, a lethal effect of $\mathrm{Pb}$ on C. vulgaris was observed at $1 \mathrm{mM} \mathrm{Pb}$ (Bajguz 2000a). Cao et al. (2015) demonstrated that $2.4-4.8 \mu \mathrm{M} \mathrm{Pb}$ accelerated the growth of Cladophora, while $\mathrm{Pb}$ up to $48 \mu \mathrm{M}$ inhibited their growth. Moreover, photosynthesis was limited under heavy metal stress. The outcomes of the correlation analysis showed that the $\mathrm{Pb}$ content in Cladophora was significantly correlated with growth and peroxidase (POD), MDA, and metallothionein levels.

In adverse environmental conditions, plants activate different defense strategies against heavy metals, e.g., by regulation of antioxidants system and the synthesis of PCs. BRs can regulate many aspects of growth and responses to stresses (Krishna 2003; Bajguz and Hayat 2009; Rajewska et al. 2016). BRs have an anti-stress effect on C. vulgaris exposed to heavy metals (Bajguz 2000a, 2002, 2010, 2011). The present study revealed 
Cultivation time in day:

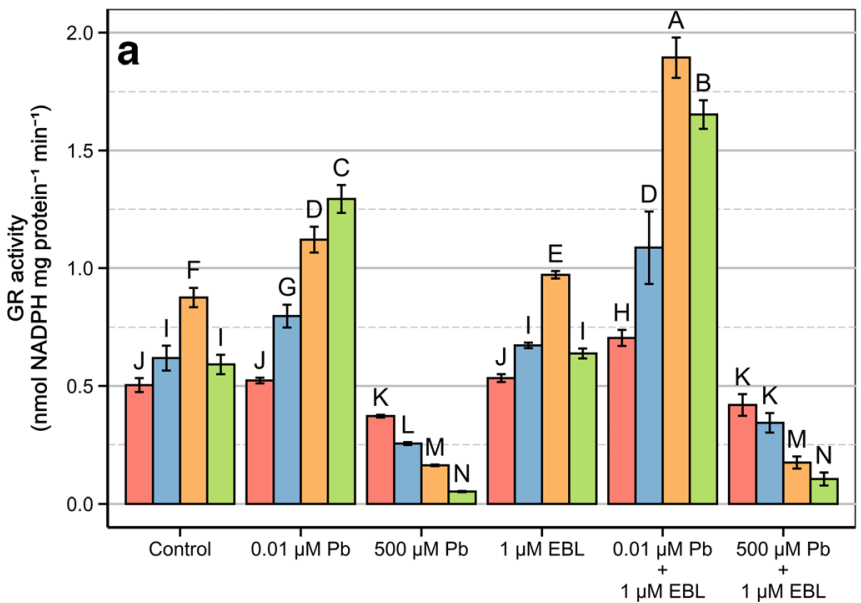

Fig. 5 The effect of lead and/or 24-epibrassinolide (EBL) on the activity of glutathione reductase (GR, a) and the content of glutathione (GSH, b) in Acutodesmus obliquus. Bars show the mean $(n=5)$ with standard

the considerable impact of $1 \mu \mathrm{M}$ EBL in the decrease in the level of $\mathrm{Pb}$ in response to metal treatments in A. obliquus culture. The largest effect of EBL in decreasing accumulate of $\mathrm{Pb}$ was observed after the application of $0.01 \mu \mathrm{M} \mathrm{Pb}$ (Fig. 1b). Previous studies described a notable decline in the copper $(\mathrm{Cu})$, cadmium $(\mathrm{Cd})$, and $\mathrm{Pb}$ accumulation in $C$. vulgaris cultures treated with exogenous BR (Bajguz 2000a, 2002, 2010, 2011). In the case of higher plants, such as tomato, barley, spring wheat, mustard, and radish, application of EBL also significantly reduced the metal absorption by more than $50 \%$ lower relative to the control condition in sugar beet roots (Khripach et al. 2000; Kroutil et al. 2010; Bajguz 2011; Kanwar et al. 2012). Growth inhibition was associated with the concentration of heavy metal in algal cell and the number of metal ions bound to the cell surface and intracellular metal ions, as well as to the chemical character of the metal (Tripathi et al. 2006; Polonini et al. 2015). In our experiment, $\mathrm{Pb}$ toxicity resulted in a decrease of A. obliquus growth, which was restored by the application of EBL (Fig. 1a). Similarly, Bajguz (2010) showed that the application of BL improved the growth of $C$. vulgaris cultures treated with heavy metals. Other studies have confirmed that growth suppression of mustard (Brassica juncea) treated with nickel (Ni) (Alam et al. 2007; Ali et al. 2008b; Kanwar et al. 2012), aluminum (Al) in mungbean (Vigna radiata) (Ali et al. 2008a), as well as Cd in chickpea (Cicer arietinum) (Hasan et al. 2008) and radish (Raphanus sativus) (Anuradha and Rao 2007), was restored by exogenous BR. The favorable role of BRs in the regulation of plant growth in the presence of metal has been reported by many researchers. It suggests that the

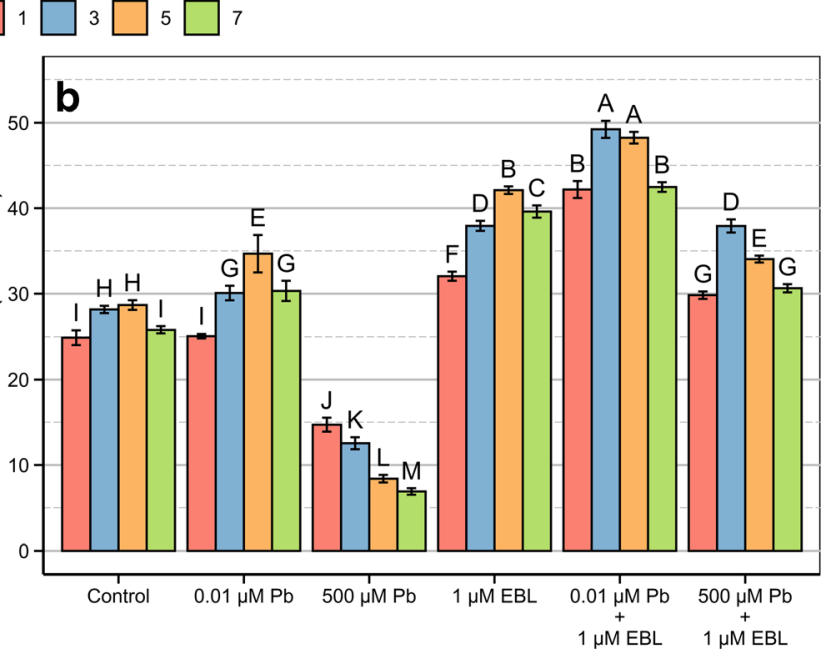

deviation. Means with the same letters are not significantly different ( $p$ $\geq 0.05$ ) according to Scott-Knott's post-hoc test. Data were grouped by the day of cultivation and treatment for each pigment

relationship between phytohormones and metal might be used as a defense mechanism against heavy metal toxicity.

Proteins are crucial markers of irreversible and reversible changes in plant metabolism (Singh et al. 2006). $\mathrm{Pb}$ excess in A. obliquus caused the inability of cells to accumulate proteins. However, this study indicates that the addition of EBL might be useful to induce the biosynthesis of protein (Fig. 1c). The co-application of EBL and Pb led to a greater amount of protein (almost double increase) than the action of $\mathrm{Pb}$ alone. Bajguz (2011) also indicated that the inhibitory effect of $\mathrm{Cu}, \mathrm{Pb}$, and $\mathrm{Cd}$ on the protein content in C. vulgaris cells was suppressed by EBL. In the case of higher plants, Choudhary et al. (2012) found that the application of $1 \mu \mathrm{M}$ EBL to chromium (Cr) stressed radish seedlings increased the content of protein in comparison to plant treated with $\mathrm{Cr}$ alone. Solanum lycopersicum treated with EBL showed a greater protein content than the control despite the presence Ni stress (Nazir et al. 2019). Zhou et al. (2018) showed that the content of protein significantly increased after the application of EBL in grape (Vitis vinifera) under $\mathrm{Cu}$ stress. Hence, the declining content of protein in algal cells and higher plants treated with $\mathrm{Pb}$ can be restored by applying EBL, which increases the chances of plant survival in ecosystems polluted with heavy metals.

Couée et al. (2006) presented the theory that soluble sugars can play a double role with regard to reactive oxygen species (ROS) by engaging or relating to ROSproducing metabolic pathways. On the other hand, soluble sugars could also boost NADPH-producing metabolic pathways, for example the oxidative pentose-phosphate pathway, which can cooperate with ROS scavenging. Our research confirmed the stimulating impact of EBL 
on the monosaccharide content in A. obliquus treated with $\mathrm{Pb}$ (Fig. 1d). We also noted a rise in the content of this parameter (by 10-80\%) when treated with EBL plus $\mathrm{Pb}$ mix, relative to $\mathrm{Pb}$ alone. Bajguz (2011) reported that heavy metals $(\mathrm{Cu}, \mathrm{Cd}$, and $\mathrm{Pb})$ biosorption is negatively correlated with monosaccharides contents in $C$. vulgaris cultures treated with BL. In the case of two wheat Triticum aestivum cultivars (LOK-1 and 502), the application of EBL enhanced the sugar content. Moreover, the maximum rise in the content of sugar was detected in the plants treated with the combination of $\mathrm{Al}$ and salt stress and sprayed with EBL in LOK-1 (Yusuf et al. 2017).

The $\mathrm{Pb}$-induced cellular damage in microalgal cells could be monitored by the decrease in the chlorophylls content. The high concentration of heavy metal might limit biosynthesis of pigment and enzymes that are involved in this process (Bajguz 2011; Piotrowska-Niczyporuk et al. 2015). The decrease in pigment content in algae under metal stress might also be caused by peroxidation of chloroplast membranes through the intensification of ROS production (Bajguz 2011). Our results demonstrate that the reduction of chlorophylls content in A. obliquus treated with $\mathrm{Pb}$ was prevented by EBL (Table 1). The combination of EBL and Pb showed a significant increase in the content of chlorophylls in the algal cells when compared with $\mathrm{Pb}$ treatment alone. According to Bajguz (2011), an increase of the chlorophyll content was noted in the $C$. vulgaris cultures exposed to EBL mixed with $\mathrm{Cu}, \mathrm{Pb}$ or $\mathrm{Cd}$. Wu et al. (2019) confirmed that antimony (Sb) exposure $(50 \mu \mathrm{M})$ led to a marked decrease in the content of chlorophylls in Arabidopsis thaliana leaves but exogenous $0.01 \mu \mathrm{M}$ EBL application strongly alleviated this adverse effect. Similar stimulating effects of EBL were reported by Guo et al. (2018), who showed that EBL increases the content of chlorophylls $a$ and $b$ in $\mathrm{Cd}$ stressed tomato plants. Additionally, Yusuf et al. (2016) also presented that SPAD chlorophyll has been significantly enhanced in the presence of EBL under $\mathrm{Cu}$ stress or stress-free conditions, whereas $\mathrm{Cu}$ alone lowered the chlorophyll content in the mustard plant. On the other hand, under iron deficiency in Eucalyptus urophylla plants, $100 \mathrm{nM}$ EBL effectively increased chlorophylls $a$ and $b$, and total chlorophylls contents and chlorophyll fluorescence (Lima et al. 2018).

The carotenes and xanthophylls can free radical quenching and might protect the photosynthetic apparatus against oxidative stress, for example, by heavy metals (Janik et al. 2010; Lavoie et al. 2016). Hence, the increased accumulation of carotenes observed in A. obliquus exposed to $\mathrm{Pb}$ can explain the oxidative stress enhancement. Furthermore, these experiments confirmed the contribution of EBL to the increased resistance to carotenes degradation in algal treated with $\mathrm{Pb}$ (Table 1). A substantial rise in the content of xanthophylls (by 19-117\%) was detected, after application of EBL with Pb. Similarly, an increase of $20 \%$ in total carotenoids content was also observed by Lin et al. (2018) in C. vulgaris cultures treated with $1 \mu \mathrm{M}$ EBL. Other studies show that EBL increased the pigment levels, i.e., chlorophyll $a(83 \%)$, chlorophyll $b(68 \%)$, and carotenoids $(61 \%)$ in $\mathrm{Cr}$-stressed radish seedlings (Choudhary et al. 2012).

A diversity of ROS is generated as an answer of plants to metal stress. Exposure to $\mathrm{Pb}$ accelerated the ROS production, including $\mathrm{H}_{2} \mathrm{O}_{2}$, hence unbalancing the cellular redox status in A. obliquus. ROS react with cellular components (lipids, nucleic acids, proteins, and pigments) to cause lipid peroxidation, enzyme inactivation, and membrane damage (Ahmad 2016; Maia et al. 2018). MDA level is used as an index of lipid peroxidation because it is an indicator of free radical formation in the tissues exposed to adverse environmental conditions (Cuypers et al. 2016). The present study showed that the application of EBL decreased the level of MDA and $\mathrm{H}_{2} \mathrm{O}_{2}$ content by about $20-60 \%$ in $\mathrm{Pb}$-stressed $A$. obliquus cells, relative to cultures treated with heavy metal alone (Fig. 2a, b). It was shown that microalgae exposed to EBL exhibited higher membrane stability index and reduced peroxidation of membrane lipid, and also a decrease in ROS content. Similarly, the application of EBL reduces the level of MDA and $\mathrm{H}_{2} \mathrm{O}_{2}$ in Ni-stressed Solanum nigrum seedlings (Soares et al. 2016). In the presence of EBL, the level of oxidative radicals was reduced in Solanum lycopersicum growing under Ni stress (Nazir et al. 2019). According to Wu et al. (2019), foliar application of $0.01 \mu \mathrm{M}$ EBL induced a slight decline in the content of MDA (by 15\%) in A. thaliana under $50-\mu \mathrm{M} \mathrm{Sb}$ stress relative to the control. However, in relation to seedlings treated by $\mathrm{Sb}$ alone, the level of $\mathrm{H}_{2} \mathrm{O}_{2}$ increased (by 27\%) after application of $\mathrm{Sb}$ and EBL. Moreover, EBL mitigated the negative effects oxidative stress in cowpea plants (Vigna unguiculata) exposed to Cd toxicity by reducing the content of MDA, with decreases in lipid peroxidation and escape of electrolytes (Santos et al. 2018).

BRs can regulate the stress response by modifying the level of antioxidants (Bajguz and Hayat 2009). Our experiments found that EBL significantly enhanced the activity of antioxidants in A. obliquus exposed to metal (Figs. 2c-f and 5a, b). Bajguz (2010) previously reported that BL activated both enzymatic and non-enzymatic antioxidants in $C$. vulgaris treated with $\mathrm{Cu}, \mathrm{Pb}$, and $\mathrm{Cd}$. Ali et al. (2008a) noted that the foliar spray of either with EBL or 28-homobrassinolide meaningfully intensified the content of antioxidant enzymes in Alstressed mungbean plants. Moreover, EBL enhanced the activity of SOD, CAT, GR, and POD in mustard plants grown 
under both $\mathrm{Ni}$ stress and stress-free conditions (Ali et al. 2008b). Similarly, exogenous $0.01 \mu \mathrm{M}$ EBL application provoked an increase in the activity of enzymatic antioxidants and proline content in A. thaliana compared to seedlings treated with $\mathrm{Sb}$ alone (Wu et al. 2019). Also, the optimal performance in the alleviation of $\mathrm{Cu}$ toxicity was noted after application of $0.2 \mu \mathrm{M}$ EBL. The balance of the ascorbate-GSH cycle in grape cuttings was also regulated by increasing the activities of monodehydroascorbate and dehydroascorbate reductase, as well as GR, APX, and the contents of the antioxidant ascorbate and dehydroascorbic acid. However, the contents of GSH and oxidized glutathione decreased (Zhou et al. 2018). Furthermore, Kapoor et al. (2016) reported that EBL alleviated the harmful impact of $\mathrm{Cd}$ in radish seedlings (Raphanus sativus) by enhancing the level of antioxidants, such as ascorbic acid, GSH, and tocopherols. In the case of soybean seedlings (Glycine max) (Ribeiro et al. 2019) and cowpea (Vigna unguiculata) (Lima and Lobato 2017) under water deficit conditions and Eucalyptus urophylla exposed to salt stress (Oliveira et al. 2019), EBL caused increases in SOD, CAT, APX, and POX activities, indicating that BR has a significant impact on the antioxidant system in plants subjected to abiotic stresses. Additionally, EBL reduced the superoxide and $\mathrm{H}_{2} \mathrm{O}_{2}$ levels as well as membrane damages (MDA and electrolyte leakage) in soybean under water deficit (Pereira et al. 2019).

The chelation of the metal ions by PC is one of the mechanisms of heavy metal detoxification in plants. PC are cysteine-rich polypeptides derived from GSH. The enzymatically catalyzed PC synthesis reaction requires the presence of PCS (Bajguz 2002; Cobbett and Goldsbrough 2002; Grill et al. 2007; Pal and Rai 2010; Rajewska et al. 2016). The improved PCS activity in algae treated with $\mathrm{EBL}$ and $\mathrm{Pb}$ was concurrent with the highly raised level of $\mathrm{PC}_{4}$, suggesting that the polymerization of $\mathrm{PC}_{2}$ into $\mathrm{PC}_{3-5}$ was a direct consequence of a higher PCS activity noted under the highest concentration of $\mathrm{Pb}$ (Figs. $3 \mathrm{a}$ and 4). The results reported by Scarano and Morelli (2002) indicate that $\mathrm{Pb}$ and $\mathrm{Cd}$ are capable of inducing the PC synthesis and form stable complexes with $\mathrm{PC}_{3-6}$ in a marine microalga Phaeodactylum tricornutum. Moreover, Scenedesmus vacuolatus exposure to $80-800 \mathrm{pM}$ $\mathrm{Pb}$ resulted in more than twofold GSH increase; the synthesis of $\mathrm{PC}_{2}$ was noted (Le Faucheur et al. 2006). Present results suggest that $\mathrm{EBL}$ is involved in the synthesis of $\mathrm{PC}$ in response to $\mathrm{Pb}$ stress (Figs. 3a and 4). In general, EBL has a meaningful impact on the detoxification of metal by boosting PC synthesis.

\section{Conclusion}

In the study, EBL was applied to mitigate $\mathrm{Pb}$ stress in the green alga A. obliquus for the first time. After applying
$1 \mu \mathrm{M}$ EBL to the alga treated with 0.01 and $500 \mu \mathrm{M} \mathrm{Pb}$, EBL effectively mitigated the toxic effect of $\mathrm{Pb}$ on protein and sugar as well as chlorophylls and carotenoids content. $\mathrm{Pb}$ limited the algal growth and metabolism which was then restored by the application of EBL. Thus, EBL enhanced the antioxidants, GSH, and PC levels as well as reduced the endogenous level of $\mathrm{Pb}$. These facts confirm that EBL accelerates the metal detoxification and has an anti-stress activity in A. obliquus occurring in $\mathrm{Pb}$-polluted water.

Authors' contributions Concept of the study: $\mathrm{AB}$; collection and assembly of data: MT-K; drafting of the article: MT-K; analysis and interpretation of the data: MT-K, AP-N; statistical analysis: AB; critical revision and important intellectual content: $\mathrm{AB}$; final approval of the article: all authors

Funding information This project has been financed from the funds of the National Science Centre allocated based on the decision number DEC-2012/05/B/NZ8/00958. This work was funded by the Ministry of Science and Higher Education as part of subsidies for maintaining research potential awarded to the Faculty of Biology and Chemistry of the University of Bialystok.

Open Access This article is distributed under the terms of the Creative Commons Attribution 4.0 International License (http:// creativecommons.org/licenses/by/4.0/), which permits unrestricted use, distribution, and reproduction in any medium, provided you give appropriate credit to the original author(s) and the source, provide a link to the Creative Commons license, and indicate if changes were made.

\section{References}

Aebi H (1984) Catalase in vitro. Methods Enzymol 105:121-126

Ahmad P (2016) Plant metal interaction: emerging remediation techniques. Elsevier, Amsterdam

Alam MM, Hayat S, Ali B, Ahmad A (2007) Effect of 28homobrassinolide treatment on nickel toxicity in Brassica juncea. Photosynthetica 45:139-142

Ali B, Hasan SA, Hayat S, Hayat Q, Yadav S, Fariduddin Q, Ahmad A (2008a) A role for brassinosteroids in the amelioration of aluminium stress through antioxidant system in mung bean (Vigna radiata $\mathrm{L}$. Wilczek). Environ Exp Bot 62:153-159

Ali B, Hayat S, Fariduddin Q, Ahmad A (2008b) 24-Epibrassinolide protects against the stress generated by salinity and nickel in Brassica juncea. Chemosphere 72:1387-1392

Andersen RA (ed) (2005) Algal culturing techniques. Academic Press, Amsterdam

Andersen RA, Berges JA, Harrison PJ, Watanabe MM (2005) Appendix A - Recipes for freshwater and seawater media. In: Andersen RA (ed) Algal Culturing Techniques. Academic Press, Amsterdam, pp 429-538

Anuradha S, Rao SSR (2007) The effect of brassinosteroids on radish (Raphanus sativus L.) seedlings growing under cadmium stress. Plant Soil Environ 53:465-472

Arora P, Bhardwaj R, Kanwar MK (2012) Effect of 24-epibrassinolide on growth, protein content and antioxidative defense system of Brassica juncea L. subjected to cobalt ion toxicity. Acta Physiol Plant 34:2007-2017

Bajguz A (2000a) Blockade of heavy metals accumulation in Chlorella vulgaris cells by 24-epibrassinolide. Plant Physiol Biochem 38: 797-801 
Bajguz A (2000b) Effect of brassinosteroids on nucleic acids and protein content in cultured cells of Chlorella vulgaris. Plant Physiol Biochem 38:209-215

Bajguz A (2002) Brassinosteroids and lead as stimulators of phytochelatins synthesis in Chlorella vulgaris. J Plant Physiol 159: 321-324

Bajguz A (2010) An enhancing effect of exogenous brassinolide on the growth and antioxidant activity in Chlorella vulgaris cultures under heavy metals stress. Environ Exp Bot 68:175-179

Bajguz A (2011) Suppression of Chlorella vulgaris growth by cadmium, lead, and copper stress and Its restoration by endogenous brassinolide. Arch Environ Contam Toxicol 60:406-416

Bajguz A (2019) Brassinosteroids in microalgae: application for growth improvement and protection against abiotic stresses. In: Hayat S, Yusuf M, Bhardwaj R, Bajguz A (eds) Brassinosteroids: Plant Growth and Development. Springer Singapore, Singapore, pp 4558

Bajguz A, Asami T (2004) Effects of brassinazole, an inhibitor of brassinosteroid biosynthesis, on light- and dark-grown Chlorella vulgaris. Planta 218:869-877

Bajguz A, Czerpak R (1998) Physiological and biochemical role of brassinosteroids and their structure-activity relationship in the green alga Chlorella vulgaris Beijerinck (Chlorophyceae). J Plant Growth Regul 17:131-139

Bajguz A, Hayat S (2009) Effects of brassinosteroids on the plant responses to environmental stresses. Plant Physiol Biochem 47:1-8

Bajguz A, Tretyn A (2003) The chemical characteristic and distribution of brassinosteroids in plants. Phytochemistry 62:1027-1046

Beauchamp C, Fridovich I (1971) Superoxide dismutase: improved assays and an assay applicable to acrylamide gels. Anal Biochem 44: 276-287

Behnamnia M, Kalantari KM, Rezanejad F (2009) Exogenous application of brassinosteroid alleviates drought-induced oxidative stress in Lycopersicon esculentum L. Gen Appl Plant Physiol 35:22-34

Bradford MM (1976) A rapid and sensitive method for the quantitation of microgram quantities of protein utilizing the principle of protein-dye binding. Anal Biochem 72:248-254

Cakmak I, Horst WJ (1991) Effect of aluminium on lipid peroxidation, superoxide dismutase, catalase, and peroxidase activities in root tips of soybean (Glycine max). Physiol Plant 83:463-468

Cao D-j, Shi X-d, Li H, Xie P-p, Zhang H-m, Deng J-w, Liang Y-g (2015) Effects of lead on tolerance, bioaccumulation, and antioxidative defense system of green algae, Cladophora. Ecotoxicol Environ Saf 112:231-237

Choudhary SP, Kanwar M, Bhardwaj R, Yu JQ, Tran LSP (2012) Chromium stress mitigation by polyamine-brassinosteroid application involves phytohormonal and physiological strategies in Raphanus sativus L. PLoS One 7

Cobbett C, Goldsbrough P (2002) Phytochelatins and metallothioneins: Roles in heavy metal detoxification and homeostasis. Annu Rev Plant Biol 53:159-182

Couée I, Sulmon C, Gouesbet G, El Amrani A (2006) Involvement of soluble sugars in reactive oxygen species balance and responses to oxidative stress in plants. J Exp Bot 57:449-459

Cuypers A, Hendrix S, dos Reis RA, De Smet S, Deckers J, Gielen H, Jozefczak M, Loix C, Vercampt H, Vangronsveld J, Keunen E (2016) Hydrogen peroxide, signaling in disguise during metal phytotoxicity. Front Plant Sci 7

da Silva LJ (2010) Laercio-package: Duncan test, Tukey test and ScottKnott test (2010) https://CRAN.R-project.org/package = laercio. Accessed 20 February 2015

Dao LHT, Beardall J (2016) Effects of lead on growth, photosynthetic characteristics and production of reactive oxygen species of two freshwater green algae. Chemosphere 147:420-429
Finkemeier I, Kluge C, Metwally A, Georgi M, Grotjohann N, Dietz KJ (2003) Alterations in Cd-induced gene expression under nitrogen deficiency in Hordeum vulgare. Plant Cell Environ 26:821-833

Fox J, Weisberg S (2011) An R companion to applied regression, 2nd edn. SAGE Publications, Inc., Thousand Oaks

Gin KY-H, Tang Y-Z, Aziz MA (2002) Derivation and application of a new model for heavy metal biosorption by algae. Water Res 36: $1313-1323$

Grill E, Mishra S, Srivastava S, Tripathi RD (2007) Role of phytochelatins in phytoremediation of heavy metals. In: Singh SN, Tripathi RD (eds) Environmental Bioremediation Technologies. Springer, Berlin, pp 101-146

Gunetti M, Castiglia S, Rustichelli D, Mareschi K, Sanavio F, Muraro M, Signorino E, Castello L, Ferrero I, Fagioli F (2012) Validation of analytical methods in GMP: the disposable Fast Read 102® device, an alternative practical approach for cell counting. J Trans1 Med 10: 112

Guo J, Zhou R, Ren X, Jia H, Hua L, Xu H, Lv X, Zhao J, Wei T (2018) Effects of salicylic acid, epi-brassinolide and calcium on stress alleviation and $\mathrm{Cd}$ accumulation in tomato plants. Ecotoxicol Environ Saf 157:491-496

Hasan SA, Hayat S, Ali B, Ahmad A (2008) 28-Homobrassinolide protects chickpea (Cicer arietinum) from cadmium toxicity by stimulating antioxidants. Environ Pollut 151:60-66

Janik E, Maksymiec W, Gruszecki WI (2010) The photoprotective mechanisms in Secale cereale leaves under $\mathrm{Cu}$ and high light stress condition. J Photochem Photobiol B 101:47-52

Javanbakht V, Alavi SA, Zilouei H (2013) Mechanisms of heavy metal removal using microorganisms as biosorbent. Water Sci Technol 69: 1775-1787

Kampfenkel K, Vanmontagu M, Inze D (1995) Extraction and determination of ascorbate and dehydroascorbate from plant tissue. Anal Biochem 225:165-167

Kanwar MK, Bhardwaj R, Arora P, Chowdhary SP, Sharma P, Kumar S (2012) Plant steroid hormones produced under Ni stress are involved in the regulation of metal uptake and oxidative stress in Brassica juncea L. Chemosphere 86:41-49

Kanwar MK, Bajguz A, Zhou J, Bhardwaj R (2017) Analysis of brassinosteroids in plants. J Plant Growth Regul 36:1002-1030

Kapoor D, Rattan A, Gautam V, Bhardwaj R (2016) Alleviation of cadmium and mercury stress by supplementation of steroid hormone to Raphanus sativus seedlings. Proc Natl Acad Sci India Sect B 86: 661-666

Khripach V, Zhabinskii V, De Groot A (2000) Twenty years of brassinosteroids: Steroidal plant hormones warrant better crops for the XXI century. Ann Bot 86:441-447

Krishna P (2003) Brassinosteroid-mediated stress responses. J Plant Growth Regul 22:289-297

Kroutil M, Hejtmánková A, Lachman J (2010) Effect of spring wheat (Triticum aestivum L.) treatment with brassinosteroids on the content of cadmium and lead in plant aerial biomass and grain. Plant Soil Environ 56:43-50

Lavoie M, Raven JA, Jones OAH, Qian H (2016) Energy cost of intracellular metal and metalloid detoxification in wild-type eukaryotic phytoplankton. Metallomics 8:1097-1109

Le Faucheur S, Schildknecht F, Behra R, Sigg L (2006) Thiols in Scenedesmus vacuolatus upon exposure to metals and metalloids. Aquat Toxicol 80:355-361

Lima JV, Lobato AKS (2017) Brassinosteroids improve photosystem II efficiency, gas exchange, antioxidant enzymes and growth of cowpea plants exposed to water deficit. Physiol Mol Biol Plants 23:5972

Lima MDR, Barros UD, Batista BL, Lobato AKS (2018) Brassinosteroids mitigate iron deficiency improving nutritional status and photochemical efficiency in Eucalyptus urophylla plants. Trees Struct Funct 32:1681-1694 
Lin B, Ahmed F, Du H, Li Z, Yan Y, Huang Y, Cui M, Yin Y, Li B, Wang M, Meng C, Gao Z (2018) Plant growth regulators promote lipid and carotenoid accumulation in Chlorella vulgaris. J Appl Phycol 30: 1549-1561

Lourie E, Patil V, Gjengedal E (2010) Efficient purification of heavymetal-contaminated water by microalgae-activated pine bark. Water Air Soil Pollut 210:493-500

Maia CF, Silva BRS, Lobato AKS (2018) Brassinosteroids positively modulate growth: physiological, biochemical and anatomical evidence using two tomato genotypes contrasting to dwarfism. J Plant Growth Regul 37:1099-1112

Nakano Y, Asada K (1981) Hydrogen peroxide is scavenged by ascorbate-specific peroxidase in spinach chloroplasts. Plant Cell Physiol 22:867-880

Nazir F, Hussain A, Fariduddin Q (2019) Interactive role of epibrassinolide and hydrogen peroxide in regulating stomatal physiology, root morphology, photosynthetic and growth traits in Solanum lycopersicum L. under nickel stress. Environ Exp Bot 162:479-495

Oliveira VP, Lima MDR, Silva BRS, Batista BL, Lobato AKS (2019) Brassinosteroids confer tolerance to salt stress in Eucalyptus urophylla plants enhancing homeostasis, antioxidant metabolism and leaf anatomy. J Plant Growth Regul 38:557-573

Pal R, Rai JPN (2010) Phytochelatins: peptides involved in heavy metal detoxification. Appl Biochem Biotechnol 160:945-963

Pereira YC, Rodrigues WS, Lima EJA, Santos LR, Silva MHL, Lobato AKS (2019) Brassinosteroids increase electron transport and photosynthesis in soybean plants under water deficit. Photosynthetica 57:181-191

Piotrowska-Niczyporuk A, Bajguz A, Talarek M, Bralska M, Zambrzycka E (2015) The effect of lead on the growth, content of primary metabolites, and antioxidant response of green alga Acutodesmus obliquus (Chlorophyceae). Environ Sci Pollut Res 22:19112-19123

Piotrowska-Niczyporuk A, Bajguz A, Zambrzycka-Szelewa E (2017) Response and the detoxification strategies of green alga Acutodesmus obliquus (Chlorophyceae) under lead stress. Environ Exp Bot 144:25-36

Polonini HC, Brandao HM, Raposo NR, Brandao MA, Mouton L, Coute A, Yepremian C, Sivry Y, Brayner R (2015) Size-dependent ecotoxicity of barium titanate particles: the case of Chlorella vulgaris green algae. Ecotoxicology 24:938-948

Prison A, Lorenzen H (1966) Synchronized dividing algae. Annu Rev Plant Physiol 17:439-458

R: A Language and Environment for Statistical Computing (R version 3.5.3, Great Truth) (2019) R Foundation for Statistical Computing. https://www.R-project.org/.

Rajamani S, Torres M, Falcao V, Gray JE, Coury DA, Colepicolo P, Sayre $R$ (2014) Noninvasive evaluation of heavy metal uptake and storage in micoralgae using a fluorescence resonance energy transfer-based heavy metal biosensor. Plant Physiol 164:1059-1067

Rajewska I, Talarek M, Bajguz A (2016) Brassinosteroids and response of plants to heavy metals action. Front Plant Sci 7:629

Ribeiro DGS, Silva BRS, Lobato AKS (2019) Brassinosteroids induce tolerance to water deficit in soybean seedlings: contributions linked to root anatomy and antioxidant enzymes. Acta Physiol Plant 41:82-11

Santos LR, Batista BL, Lobato AKS (2018) Brassinosteroids mitigate cadmium toxicity in cowpea plants. Photosynthetica 56:591-605

Scarano G, Morelli E (2002) Characterization of cadmium- and leadphytochelatin complexes formed in a marine microalga in response to metal exposure. Biometals 15:145-151

Schaedle M, Bassham JA (1977) Chloroplast glutathione reductase. Plant Physiol 59:1011-1012

Scheidegger C, Behra R, Sigg L (2011) Phytochelatin formation kinetics and toxic effects in the freshwater alga Chlamydomonas reinhardtii upon short- and long-term exposure to lead(II). Aquat Toxicol 101: 423-429
Sharma I, Pati PK, Bhardwaj R (2011) Effect of 28-homobrassinolide on antioxidant defence system in Raphanus sativus $\mathrm{L}$. under chromium toxicity. Ecotoxicology 20:862-874

Singh S, Eapen S, D'Souza SF (2006) Cadmium accumulation and its influence on lipid peroxidation and antioxidative system in an aquatic plant, Bacopa monnieri L. Chemosphere 62:233-246

Soares C, de Sousa A, Pinto A, Azenha M, Teixeira J, Azevedo RA, Fidalgo F (2016) Effect of 24-epibrassinolide on ROS content, antioxidant system, lipid peroxidation and Ni uptake in Solanum nigrum L. under Ni stress. Environ Exp Bot 122:115-125

Somogyi M (1952) Notes on sugar determination. J Biol Chem 195:19-23

Stirk WA, Balint P, Tarkowska D, Novak O, Strnad M, Ordog V, van Staden J (2013) Hormone profiles in microalgae: gibberellins and brassinosteroids. Plant Physiol Biochem 70:348-353

Stirk WA, Balint P, Tarkowska D, Novak O, Maroti G, Ljung K, Tureckova V, Strnad M, Ordog V, van Staden J (2014) Effect of light on growth and endogenous hormones in Chlorella minutissima (Trebouxiophyceae). Plant Physiol Biochem 79:66-76

Talarek-Karwel M, Bajguz A, Piotrowska-Niczyporuk A, Rajewska I (2018) The effect of 24-epibrassinolide on the green alga Acutodesmus obliquus (Chlorophyceae). Plant Physiol Biochem 124:175-183

Tripathi BN, Mehta SK, Amar A, Gaur JP (2006) Oxidative stress in Scenedesmus sp. during short- and long-term exposure to $\mathrm{Cu}^{2+}$ and $\mathrm{Zn}^{2+}$. Chemosphere 62:538-544

Velikova V, Yordanov I, Edreva A (2000) Oxidative stress and some antioxidant systems in acid rain-treated bean plants: Protective role of exogenous polyamines. Plant Sci 151:59-66

Wang J, Chen C (2009) Biosorbents for heavy metals removal and their future. Biotechnol Adv 27:195-226

Wilde KL, Stauber JL, Markich SJ, Franklin NM, Brown PL (2006) The effect of $\mathrm{pH}$ on the uptake and toxicity of copper and zinc in a tropical freshwater alga (Chlorella sp.). Arch Environ Contam Toxicol 51:174-185

Wu C, Li F, Xu H, Zeng W, Yu R, Wu X, Shen L, Liu Y, Li J (2019) The potential role of brassinosteroids (BRs) in alleviating antimony ( $\mathrm{Sb}$ ) stress in Arabidopsis thaliana. Plant Physiol Biochem 141:51-59

Yusuf M, Khan TA, Fariduddin Q (2016) Interaction of epibrassinolide and selenium ameliorates the excess copper in Brassica juncea through altered proline metabolism and antioxidants. Ecotoxicol Environ Saf 129:25-34

Yusuf M, Fariduddin Q, Khan TA, Hayat S (2017) Epibrassinolide reverses the stress generated by combination of excess aluminum and salt in two wheat cultivars through altered proline metabolism and antioxidants. S Afr J Bot 112:391-398

Zapata M, Rodríguez F, Garrido JL (2000) Separation of chlorophylls and carotenoids from marine phytoplankton: a new HPLC method using a reversed phase $\mathrm{C}_{8}$ column and pyridine-containing mobile phases. Mar Ecol Prog Ser 195:29-45

Zhou W, Li Y, Min M, Hu B, Chen P, Ruan R (2011) Local bioprospecting for high-lipid producing microalgal strains to be grown on concentrated municipal wastewater for biofuel production. Bioresour Technol 102:6909-6919

Zhou Y-1, Huo S-f, Wang L-t, Meng J-f, Zhang Z-w, Xi Z-m (2018) Exogenous 24-epibrassinolide alleviates oxidative damage from copper stress in grape (Vitis vinifera L.) cuttings. Plant Physiol Biochem 130:555-565

Zullo MAT, Bajguz A (2019) The brassinosteroids family - structural diversity of natural compounds and their precursors. In: Hayat S, Yusuf M, Bhardwaj R, Bajguz A (eds) Brassinosteroids: Plant Growth and Development. Springer Singapore, Singapore, pp 1-44

Publisher's note Springer Nature remains neutral with regard to jurisdictional claims in published maps and institutional affiliations. 